\title{
RECONSTITUTIONS OF HARM: NOVEL APPLICATIONS OF THE LABAYE TEST SinCE 2005
}

\author{
RICHARD JOCHELSON $^{*}$ AND JAMES GACEK ${ }^{* *}$
}

\begin{abstract}
In R. v. Labaye, the Supreme Court revised the test for Criminal Code offences involving indecency and obscenity, replacing the previous community standards of tolerance test. Despite the Supreme Court's demand for positive knowledge of (risk of) harm, the Labaye test still largely protects a normative vision of society rather than promoting human sexuality and freedom of expression. The judiciary post-Labaye continue to fill evidentiary vacuums with circumstantial evidence and intangible harms, informed by judicial tastes rather than empirical harm. Labaye has also become a discursive construct that is explicative of harm in other public law arenas. This article reveals the inconsistencies in applications of the Labaye test and considers whether a more principled definition of harm is needed in indecency and obscenity cases and beyond.
\end{abstract}

\section{TABLE OF CONTENTS}

I. INTRODUCTION: PROCEEDING "INCREMENTALLY"

BEYOND INDECENCY AND OBSCENITY . . . . . . . . . . . . . . 992

II. THE HICKLIN ERA (1868-1962) . . . . . . . . . . . . . . . . . . . . . . . . . 994

III. THE COMMUNITY StANDARdS ERA $(1962-1992) \ldots \ldots \ldots \ldots \ldots \ldots 9$

IV. THE BUTLER ERA (1992-2005) . . . . . . . . . . . . . . . . . . . . . . . . 997

V. THE LABAYE ERA (2005-PRESENT) . . . . . . . . . . . . . . . . . . . 1002

VI. A WORD ON METHODS AND POST-LABAYE

APPLICATIONS OF HARMS-BASED TESTS . . . . . . . . . . . . . . . . 1004

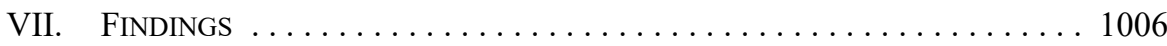

VIII. LABAYE: Discursive REFLECTIONS In Political SPEeCh,

CONSTITUTIONAL LAW, ADMINISTRATIVE LAW,

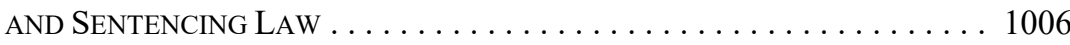

IX. LABAYE AS A DISCURSIVE BAROMETER OF

SEXUAL DYNAMISM IN CANADIAN SOCIETY

AND AS A LANDMARK OF OBJECTIVITY . . . . . . . . . . . . . . . . 1009

X. "ObJeCtively Serious" CRimes

OR OBVIOUSLY SERIOUS CRIMES . . . . . . . . . . . . . . . . . . 1013

XI. SEXUAl Risk: The SignifiCANCE OF (Risk OF) HARM

AND DisCuRSIVE COlLATERAL EFFECTS -

TO INDECENCY AND BEYOND . . . . . . . . . . . . . . . . . . . . . . . 1014

XII. IN THE LABAYE WHEELHOUSE:

Neither a Bawdy House nor Prostitution Be . . . . . . . . . . . 1022

XIII. Discussion: LABAYE CREEP . . . . . . . . . . . . . . . . . . . . . . 1023

XIV. CONCLUding THOUGHTS:

A "Cautious Step" or Caution to the Wind? . . ........... 1026

APPENDIX: BREAKDOWN OF APPLICATIONS OF LABAYE

in SAMPLE CASES Since $2005 \ldots \ldots \ldots \ldots \ldots \ldots \ldots \ldots \ldots \ldots$ 


\section{InTRODUCTION: ProceEding "INCREMENTALLY" BEYOND INDECENCY AND OBSCENITY}

R. v. Labaye 1 provided a fundamental shift in the ways in which courts would interpret Criminal Code ${ }^{2}$ offences that involved "indecency" and "obscenity" in Canadian criminal law. While the Supreme Court of Canada in Labaye recognized that the moral and legal aspects of indecency are related and that, historically, the legal concepts of indecency and obscenity - as applied to conduct and publications or expression, respectively - have been informed by the court's conception of moral views of the community, the Supreme Court could no longer support a test that seemingly depended on the tastes of members of the judiciary. ${ }^{3}$ In 2005, the Supreme Court of Canada revised the meanings of indecency and obscenity, finally retiring the beleaguered community standards of tolerance test, which had been in place prior to Labaye. ${ }^{4}$ Over time, courts have come to realize that morals and taste are "subjective, arbitrary and unworkable in the criminal context, and that a diverse society could function only with a generous measure of tolerance for minority mores and practices." The shift countenanced by the Supreme Court in Labaye adopted a new test for culpability that would be informed by a "legal norm of objectively ascertainable harm instead of subjective disapproval." Some scholars were optimistic that the Supreme Court's rationale could leave more space for sexual agency and allow greater opportunities "within legal reasoning for more diverse sexual narratives," perhaps even sex-positive narratives.

While the community standards of tolerance of harm test was rightly problematized, there has been scant academic attention paid towards the applications and implications of the new "harms-based" approach. In an attempt to address the relative void of research after Labaye, we undertake a critical analysis of court cases which have applied the harms-based test since the Labaye decision. In particular, we focus on courts' decisions to question the degree to which post-Labaye cases have called for evidence of empirical harm; after all, the majority in Labaye called for real evidence of harm in most cases. ${ }^{8}$ In other words, how have courts been applying the newly formed harm test? Are they demanding evidence to establish harm under the test applied? To date, we still have not seen any clarifying applications of the harms-based Labaye test by the Supreme Court, nor have we witnessed a profound articulation subsequently in the lower courts. We ultimately conclude that while incremental developments have been made and cautious steps have been taken in obscenity and indecency jurisprudence since the Labaye decision, Labaye still leaves behind an evidentiary vacuum that the judiciary must fill, largely with circumstantial evidence, even inferences, to

2005 SCC 80 [Labaye].

RSC 1985, c C-46.

Labaye, supra note 1 at para 14.

See e.g. Elaine Craig, "Re-Interpreting the Criminal Regulation of Sex Work in Light of R. c. Labaye" (2008) 12:3 Can Crim L Rev 327 [Craig, "Re-Interpreting"]; Elaine Craig, "Laws of Desire: The Political Morality of Public Sex" (2009) 54:2 McGill LJ 355 [Craig, "Laws of Desire"]; Richard Jochelson, "After Labaye: The Harm Test of Obscenity, the New Judicial Vacuum, and the Relevance of Familiar Voices" (2009) 46:3 Alta L Rev 741 [Jochelson, "After Labaye"]; Richard Jochelson et al, Criminal Law and Precrime: Legal Studies in Canadian Punishment and Surveillance in Anticipation of Criminal Guilt (New York: Routledge, 2018) [Jochelson et al, Criminal Law and Precrime].

Labaye, supra note 1 at para 14.

Ibid.

Craig, "Re-Interpreting," supra note 4 at 328.

Labaye, supra note 1 at para 59. 
ensure the "proper functioning of society" is maintained. ${ }^{9}$ At the end of the day, such applications may still be explicative of and informed by judicial tastes rather than empirical harm.

Recognizing the academic attention towards Labaye and its applications of harm have indeed slowed to a "veritable crawl," 10 we endeavour to engage in a discussion which revitalizes and resurges both academic inquiry and judicial cognizance on the matter. Accordingly, our previous work has reviewed the historical developments of indecency and obscenity in Canadian criminal law. ${ }^{11}$

Accordingly, we begin by reviewing the historical developments of indecency and obscenity in Canadian criminal law in four distinct phases: (1) the Hicklin era (1868-1962); (2) the community standards era (1962-1992); (3) the community standards for tolerance of harm, or Butler era (1992-2005); and (4) the "political harm," or Labaye era (2005present). ${ }^{12} \mathrm{We}$ also draw upon our previous work to illustrate "how the state has become justified in intervening in situations of attributed or even improbable 'sexual danger." undertaking jurisprudential review from R. v. Hicklin ${ }^{14}$ (1868) to Labaye (2005), we demonstrate how understanding applications of the harms-based Labaye test, in principle, provides courts with an array of justifications for criminalizing sexual expression, conduct, and materials. However, where our previous work and this article diverge is through a greater focus on the applications of the harms-based test by Canadian courts since the Labaye decision: Did Labaye change the way courts conceive of harm in the obscenity and indecency jurisprudence and other jurisprudence that followed the case? Did its harm test creep into other areas of jurisprudence?

Following a survey of the historical developments of indecency and obscenity, our article will then consider these new applications with particular focus on the case's discursive legacies. The way we prescribe harm needs context; using conceptions of harm from obscenity and indecency law in other areas of adjudications leads to a muddling of legal definitions and demonstrates a profundity of discursive and ancillary effects. Our findings suggest that, in the majority of cases, the judiciary recognize the Labaye framework as a nuanced approach to understanding issues pertaining to a number of different types of conduct and proceedings adjudicated under the law, in addition to obscenity and indecency law. Yet, the decisions are still marked by moral value judgments and, in some cases, by the absence of a rigorous explication of empirical harm in the case at hand. Many of the cases we review seek to use Labaye to justify their decisions on the basis of a significant (albeit abstract, and hence non-empirical) risk of harm to the public; for example, the courts'

$9 \quad$ Ibid at para 52.

$10 \quad$ Jochelson, "After Labaye," supra note 4 at 743.

11 Jochelson et al, Criminal Law and Precrime, supra note 4; see also Richard Jochelson \& Kirsten Kramar, Sex and the Supreme Court: Obscenity and Indecency Law in Canada (Halifax: Fernwood Publishing, 2011) [Jochelson \& Kramar, Sex and the Supreme Court]; Richard Jochelson \& Kirsten Kramar, "Governing through Precaution to Protect Equality and Freedom: Obscenity and Indecency Law in Canada after R. v. Labaye [2005]" (2011) 36:4 Can J Sociology 283 [Jochelson \& Kramar, "Governing Obscenity and Indecency"].

12 The sections which focus upon the historical development of Canada's obscenity and indecency laws build on earlier versions of our work. However, this article adds substantially to the findings with newer data, case information, and theoretical analyses.

13 Jochelson et al, Criminal Law and Precrime, supra note 4 at 47. (1868), LR 3 QB 360 [Hicklin]. 
willingness to see harm in the offing by noting the obviousness of harms in some cases allows the judiciary to obviate the need for expert evidence. Here, we are concerned with the discursive applications of the Labaye test — that harm is being supported by the underlying logics of Labaye, which may be less compelling outside of the context of sexual speech and performance.

In the coming pages, we review the history of the obscenity and indecency harm test starting with first principles in Victorian society leading up to the Labaye and R. v. Kouri ${ }^{15}$ decisions. We then discuss some interesting explications of Labaye from a group of 48 cases that we discovered when looking for cases that used Labaye in their adjudication. From those groups of cases we discuss thematic trends that emerged in the case review process: the use of Labaye discourse in considering harm in non-sexual materials - political speech, constitutional law, administrative law, and sentencing law; its use as a barometer of harm indicating dynamism in sexual mores as well as objectivity of harms in sexually explicit scenarios; its use as indicative of harms in crimes that are objectively serious or obviously serious; the use of Labaye as a means of determining impermissible societal and sexual risk; and the difficulty of finding bawdy house harms in the offing, especially in light of the current definition of "bawdy house" in section 197 of the Criminal Code - a place kept for the practices of indecency (prostitution has been removed by Parliament in the newest Criminal Code definition, which has caused difficulties for some courts in finding bawdy house harms after Labaye).

We conclude by noting some challenges for the Labaye harm test going forward. Some of the challenges remain the same as immediately after the case - the opaqueness of establishing harm, the questions about the kinds of evidence that can establish harm, and the apparent contradiction of the test in instantiating an objective, even empirical, harm test while at the same time conceding that attitudes and norms change over time (so that at least some prongs of the Labaye test must be contextually sensitive even while the categories of Labaye harm are not closed). The importation of these difficulties into areas of the law beyond indecency and obscenity creates even more saliency in these critiques.

\section{THE HICKLIN ERA (1868-1962)}

The English court case Hicklin ${ }^{16}$ set the governing standard for indecency and obscenity in Canada for nearly a century. ${ }^{17}$ Derived from Victorian and Judeo-Christian morality, the construction of the Hicklin decision lays bare the Victorian sensibilities underpinning sexual regulation in the law. Far from a central focus of risk or risk of harm, the original intention of the Hicklin decision was condemnation of the immoral. ${ }^{18}$ Dichotomy of Freedom of Expression \& Obscenity: An Anti-Censorship Perspective" (2017) 40:3 Man LJ 365 [Yan, "Freedom of Expression \& Obscenity"].

Jochelson et al, Criminal Law and Precrime, supra note 4. See also James Gacek \& Richard Jochelson, "'Animal Justice' and Sexual (Ab)use: Consideration of Legal Recognition of Sentience for Animals in Canada" (2017) 40:3 Man LJ 337. 
In Hicklin, Lord Cockburn proposed an obscenity test which would influence indecency and obscenity cases arising in Canada, the United States, and England. This test would be the earliest common law juridical test established and was primarily concerned with the corruption of morals, especially among the "weak minded" within society. The Hicklin test asked "whether the tendency of the matter charged as obscenity is to deprave and corrupt those whose minds are open to such immoral influences, and into whose hands a publication of this sort may fall."19 If the answer to this question was in the affirmative, then the impugned material was declared to be and rendered obscene. However, the Court's concern — and its subsequent harms-based test — was not for the members of the upper class who might take possession of obscene materials. Rather, the concern fell onto the regulation of the "dangerous" working classes - namely, the young, the uneducated, the women, and those "who were 'irrational' and unable to resist the material's influences." ${ }^{20}$ Justified on grounds of protection from moral harm and to secure those in society who were allegedly susceptible to moral vulnerability (irrespective of attaining viable evidence to suggest otherwise), criminal regulation through the Hicklin test was therefore produced and sustained.

Following the Hicklin precedent, only five Canadian cases were reported between 1900 and 1940 following Hicklin's codification of obscenity. ${ }^{21}$ Protections from moral harm ranged from intoxicants like alcohol and drugs to the strict regulation of pornography, as lax regulations on these alleged vices would be consumed by the "morally inferior" lower classes and consequently endanger society's proper functioning. In effect, the Hicklin obscenity test had secured "proper" moral and social values within the nuclear family unit all the while regulating the "dangerous" working classes.

\section{The Community Standards Era (1962-1992)}

The Supreme Court of Canada introduced the community standards test in R. v. Brodie, ${ }^{22}$ shortly after the enactment of what is now section 163(8) of the Criminal Code. In light of the new legislation, the Supreme Court had to decide how to apply Hicklin to Brodie and ultimately redefined the Hickin test to fit within the aims of this new legislation. The issue confronting the Supreme Court in Brodie was the criminal prosecution of D.H. Lawrence's Lady Chatterley's Lover. As a technique for determining tolerance of harm in the community, here the Supreme Court started to appeal to positivist research in the social sciences. ${ }^{23}$ Whereas Hicklin had authorized the upper classes to proscribe access to sexually explicit materials on the basis of their moral judgment of others' corruptibility, the Brodie Supreme Court envisioned and interpreted the "community" differently. The test for obscenity was now whether "the undue exploitation of sex is a dominant characteristic." 24 The application of such a test required that the work must be read in toto in order to determine its dominant purpose. ${ }^{25}$

Hicklin, supra note 14 at para 371.

Jochelson, "After Labaye," supra note 4 at 745.

Jochelson et al, Criminal Law and Precrime, supra note 4.

[1962] SCR 681 [Brodie].

Jochelson et al, Criminal Law and Precrime, supra note 4 at 49.

Brodie, supra note 22 at 702.

Ibid. 
Writing for the majority of the Supreme Court in Brodie, Justice Judson noted that community standards were relevant in deeming whether undue exploitation of sex had occurred since a community had tangible views of decency, cleanliness, and dirtiness. ${ }^{26}$ Per Justice Judson, should the dominant purpose of the speech in question be the undue exploitation of sex, then the material contravened the new legislation in place. However, if the dominant purpose of the material under consideration was not the undue exploitation of sex, then the material would be deemed acceptable by the community standards test. ${ }^{27}$ In effect, to determine the dominant purpose of the material, a court must consider the artistic or literary merit of the work and whether the author(s) had a serious literary purpose or the purpose was simply exploitation. ${ }^{28}$

In theory, the Supreme Court in Brodie saw "the community" as a cogent whole participating in determinations of harm, which provided a nominal space for the use of empirical research and evidence as to what "the community" would tolerate others being exposed to in relation to sexual danger. ${ }^{29}$ In practice, however, such determinations of harm were accomplished by the courts and not "the community." The judiciary represented the view of "the community," and this representation became an implicit notion in the community standards test. In fact, the technique for constituting what would fall within the purview of sexually explicit material deemed harmful to society was not much different than the rationale that had underpinned the Hicklin test.

For instance, the test for obscenity was further developed in $R$. v. Dominion News and Gifts Ltd. ${ }^{30}$ The Supreme Court in their decision supported Justice Freedman's dissent in the Manitoba Court of Appeal, which concluded that the community standards "should be an average of the community's thinking." ${ }^{31}$ The community standard was somewhere between the lowest, most base, and most puritan tastes, ${ }^{32}$ and using this test, the views of the margins of Canadian society would be excised to produce a more acceptable, "middle of the road" standard. Per Justice Freedman, this approach would avoid a "subjective approach," with the results varying with or depending on "the personal tastes and predilections of the particular judge who happens to be trying the case. ${ }^{\prime 33}$ In reality, few if any obscenity trials were held before juries, and yet according to Justice Judson in the Brodie decision, the best arbiter of the community was the jury, not the judiciary: "There does not exist in any community at all times - however the standard may vary from time to time - a general instinctive sense of what is decent and what is indecent, of what is clean and what is dirty, and when the

\footnotetext{
Ibid at 705 .

Ibid at 702 .

Ibid at $702-703$.

Jochelson et al, Criminal Law and Precrime, supra note 4 at 49-50.

[1964] SCR 251 [Dominion SCC].

Jochelson, "After Labaye," supra note 4 at 746. In Labaye, supra note 1 at para 55, Chief Justice McLachlin even cited with approval Justice Freedman's now nearly half-century-old observation, suggesting that the standard of what is acceptable in interpersonal and sexual activities has evolved over time. See R v Dominion News and Gifts Ltd, [1963] 42 WWR 65 (Man CA) at 80 [Dominion CA] where Justice Freedman states: "Times change, and ideas change with them. Compared to the Victorian era this is a liberal age in which we live. One manifestation of it is the relative freedom with which the whole question of sex is discussed."

Dominion CA, ibid.

Ibid.
} 
distinction has to be drawn, I do not know that today there is any better tribunal than a jury to draw it." 34

The test was further refined and reinforced in R. v. Towne Cinema Theatres Ltd., ${ }^{35}$ in which the Supreme Court underscored the importance of liberal tolerance towards others to avoid projecting "one's own personal ideas of what is tolerable." 36 This test of obscenity was to be about "a standard of tolerance, not taste" and was concerned not with what Canadians would tolerate being exposed to themselves, but with what they would tolerate other Canadians seeing. ${ }^{37}$ Therefore, we see in this passage one of many efforts to cloak the community standards test in objectivity. In doing so, this development indicated that the judiciary could infer the community standards from their own knowledge of Canadian attitudes about sexuality, rather than using substantiated empirical evidence of Canadian attitudes. $^{38}$

\section{THE BUTLER ERA (1992-2005)}

The view of community standards was further advanced and reformulated in R. v. Butler, ${ }^{39}$ the first Supreme Court of Canada case to apply the approach in an obscenity case since the inception of the Canadian Charter of Rights and Freedoms. ${ }^{40}$ In Butler, the Supreme Court was adjudicating the constitutionality of the obscenity provisions in the Criminal Code. The Supreme Court concentrated on the anti-pornography campaign as set out by one intervener, the Women's Legal Education and Action Fund (LEAF). In particular, LEAF “sought to have obscenity described as an exercise of sex discrimination that harms women's equality." ${ }^{41}$ Disagreeing with LEAF was another intervener, The British Columbia Civil Liberties Association (BCCLA), which sought to protect freedom of expression. The BCCLA was more concerned with the effects of criminal regulation on sexual freedom than speculative harms associated with allegedly obscene materials. ${ }^{42}$ Consequently, the Supreme Court's decision largely sided with the policies underlying LEAF's arguments and indeed the majority ruled the obscenity provisions to be a justifiable infringement on the freedom of expression for the aggrieved video store owner.

The Supreme Court also significantly clarified the common law definition of obscenity for the purposes of criminal liability in Butler. Justice Sopinka, writing for the majority, stated that there is sufficient evidence that depictions of degrading and dehumanizing sex harms society and, in particular, adversely affects attitudes towards women and, in some cases, men. ${ }^{43}$ However, the Supreme Court acknowledged that there is no direct link between pornography and discrimination or violence against women. ${ }^{44}$

$R v$ Close, [1948] VLR 445 at 465, Fullagar J, cited in Brodie, supra note 22 at 705.

[1985] 1 SCR 494.

Ibid at 508.

Ibid [emphasis in original].

Jochelson, “After Labaye," supra note 4 at 746; Jochelson et al, Criminal Law and Precrime, supra note 4 at 50 .

[1992] 1 SCR 452 [Butler].

Part I of the Constitution Act, 1982, being Schedule B to the Canada Act 1982 (UK), 1982, c 11 [Charter].

Yan, "Freedom of Expression \& Obscenity," supra note 17 at 377.

Jochelson \& Kramar, Sex and the Supreme Court, supra note 11 at 41.

Butler, supra note 39 at 479.

Ibid. 
Yet, the mere belief that such a connection exists could justify the suppression of pornographic speech. ${ }^{45}$ The Supreme Court in Butler recast the community standards test as a type of harm test, setting out a three-tiered test for determining which materials would fail the community standards of tolerance for harm (undue exploitation) test, which flowed from the Supreme Court's interpretation of pre-Charter case law. The three tiers included: (1) explicit sex with violence, (2) explicit sex without violence but which subjected people to treatment that was degrading or dehumanizing, and (3) explicit sex without violence that was neither degrading nor dehumanizing that did not involve children. ${ }^{46}$ Only the first two tiers counted as potentially "obscene" for legal purposes (category 1 always being violative and category 2 only being violative in the case of substantial risk of harm).

Per the Supreme Court in Butler, the community would not tolerate the undue exploitation of sex because such exploitation caused harm to not only the participants but to men and women more broadly as they are all citizens of a liberal democracy who ought to be protected from harm. ${ }^{47}$ In this context, harm would run across a broad spectrum, ranging from the harms which degrade or dehumanize some as a result of the promulgation of pornography throughout society to the harms imposed on those who actively participate in creating pornography. Most notably, the Supreme Court in Butler recognized that harm could include harm to equality, ${ }^{48}$ a right guaranteed within the Charter. In essence, criminalization was justified to prevent harm to political values — such as equality in the context of degradation and dehumanization of women - and ensured society's proper functioning as a result.

The Supreme Court would return to the community standards of tolerance test in Little Sisters Book and Art Emporium v. Canada (Minister of Justice). ${ }^{49}$ In Little Sisters, the Supreme Court was charged with examining the constitutionality of a customs regime and administrative practice and to determine whether a queer ${ }^{50}$ bookshop was being unfairly targeted and having its freedom of expression supressed by customs' allegedly discriminatory practices. Here, the Supreme Court in Little Sisters would consider the actions of the customs' officials in allegedly suppressing a host of sexually expressive material; such material seized over the years "not only included queer erotica but also ranged from sex education materials for the community to anthologies and essay collections." 51 Justice Binnie, writing for the Supreme Court majority, found that with the exception of the reverse onus provision in section $152(3)$ of the Customs Act, ${ }^{52}$ the legislation constituted a reasonable limit on the freedom of expression guaranteed in the Charter. In particular, the majority noted that "the appellants suffered differential treatment when compared to importers of heterosexually explicit material, let alone more general bookstores that carried

Ibid.

Ibid at 484 .

Jochelson et al, Criminal Law and Precrime, supra note 4 at 51-52.

Butler, supra note 39 at 479.

2000 SCC 69 [Little Sisters].

As we indicate elsewhere, we propose to use the term to refer to and recognize any or all of the following: people who identify themselves as gay, lesbian, bisexual, questioning, transgender, twospirited, and intersex. See Jochelson, "After Labaye," supra note 4 at 748.

Ibid.

RSC 1985, c 1 (2nd Supp), s 152(3) provides that "in any proceeding under this Act, the burden of proof in any question relating to ... the compliance with any of the provisions of this Act or the regulations in respect of any goods" lies on the importer. 
at least some of the same titles" as the appellant bookstore..$^{53}$ The majority was thus able to conclude that the customs officials' discretion was not exercised in accordance with Charter values, and that the administration of the scheme was violative of the freedom of expression. $^{54}$

Despite its analysis in the justification phase of constitutional analysis, the Supreme Court in Little Sisters did consider the meaning of community standards for the purposes of determining obscenity. ${ }^{55}$ Counsel for Little Sisters Book and Art Emporium and the supporting interveners ${ }^{56}$ argued that the community standards of tolerance test either needed to be applied so as to account for the unique needs of queer communities or was not the appropriate test to apply to queer communities. The Supreme Court considered and dismissed these arguments in respect of Butler, and it did so notwithstanding its acknowledgment that it could not engage in a wide-ranging consideration of Butler as no party provided a constitutional notice of this issue. ${ }^{57}$ The Supreme Court majority refused to accept that queer sexual expression created by and for the queer community was in any way distinct from heterosexual sexual expression or deserving of unique consideration, noting that the critique of the community standards test as overtly majoritarian and unduly relying on a judge's personal taste was unfounded as "[a] concern for minority expression is one of the principal factors that led to adoption of the national community test." ${ }^{, 58}$ Furthermore, the Supreme Court found that the test could not discriminate against homosexuals, as the test for obscenity was aimed at criminalizing expression that was incompatible with Canadian society as informed by equality concerns. ${ }^{59}$

In the 13 years following Butler, the Supreme Court was provided few opportunities to directly rule on the issue of criminal liability for harm for indecency and obscenity. Only five cases during this time period addressed the issue of criminal liability in the context of indecency: R. v. Tremblay; ${ }^{60}$ R. v. Mara $;{ }^{61}$ R. v. Pelletier $;{ }^{62}$ Kouri $;{ }^{63}$ and Labaye ${ }^{64}$ These cases used the community standards for tolerance of harm test to rule whether bawdy houses, or venues where supposed indecent performances were said to have been held, were operating for the alleged purposes of indecency. In these cases, we witness the relevance of privacy as an arbiter of harm. The question of whether particular acts were criminal had drawn upon the Supreme Court's assessments of privacy. The Supreme Court in its indecency jurisprudence understands privacy as one end of a spectrum moving towards public action on the other end - and generally, the more public a display of sexuality, the

Little Sisters, supra note 49 at para 116.

Ibid at paras $123-24$.

However, it was a limited engagement and the analysis did not cement a concrete finding since no impugned expression was before the Supreme Court per se; see Little Sisters, ibid at para 53.

The factums of the interveners were diverse, varied, and highly contextualized, and regrettably we could not do justice to their many arguments within the scope of our article. For an articulation of the specific minutiae of each intervener, see Karen Busby, "Little Sister's v. Canada: What Did the Queer-Sensitive Interveners Argue about Equality Rights and Free Expression?" in Brian Burtch \& Nick Larsen, eds, Law in Society: Canadian Readings, 2nd ed (Toronto: Thomson Canada, 2006) 4.

Little Sisters, supra note 49 at para 53.

Ibid at para 56.

Ibid at para 58 .

[1993] 2 SCR 932 [Tremblay].

[1997] 2 SCR 630 [Mara].

[1999] 3 SCR 863 [Pelletier].

Supra note 15.

Supra note 1. 
more of an affront the sexual action will be to an unassuming audience. "The tacit harm assumed in such cases is that exposure to unexpected sexual performances creates a criminal risk worth sanctioning." 65

These observations were initially evident in the Supreme Court of Canada cases of Tremblay and Mara. Both cases demonstrated a concern for the issues surrounding the differences between locations "which can come within the definition of public places"; however, judicial interpretations of the law stopped short of critiquing the definition of privacy itself. ${ }^{66}$ Tremblay involved erotic dancing in a private room at an erotic club, while Mara involving erotic dancing in the open access area of a similar club. In both cases, the Supreme Court had to determine whether the conduct at issue was criminally indecent. Since the Tremblay case involved private dancing, the case was not adjudicated under the indecent public performance provisions of the Criminal Code, and the degree of privacy was relevant to the analysis, since a public display would render the indecency more egregious for the purposes of the law. The Supreme Court in Tremblay conclusively found, in terms of where the acts took place, that "sexual activities were conducted behind closed doors out of the view of the general public," ${ }^{67}$ and although "the acts took place in a public place, as those words are defined in the Criminal Code, they were not a blatantly public display. Rather, the closed room was relatively private with only consenting adults present." ${ }^{, 68}$ Writing for the Supreme Court in Mara, Justice Sopinka distinguished Mara from Tremblay, noting that "it is important to recall that Tremblay involved an analysis of whether acts performed in a private room were indecent," whereas Mara involved "an analysis of whether a performance was indecent." ${ }^{99}$ In particular, Justice Sopinka deemed the physical contact between patron and dancer as indecent — the fondling and sucking of dancers' breasts by the patrons, as well as contact between the dancer or patron and the other person's genitals - as the acts would be harmful to society through the further degradation and dehumanization of women and would desensitize those watching to sexuality. Interestingly, the risk of harm from sexually transmitted diseases and the activity's similarity to prostitution were relevant only insofar as these matters created risk of social harm - such as the social harm of acceptance or desensitization to such activities. ${ }^{70}$ As Justice Sopinka notes, "[i]ndecency depends on community standards, which in turn depend largely on an analysis of social harm"; ${ }^{71}$ social harm, then, "is not a fact susceptible of proof in the traditional way, but rather where the activities or material in question involve the degradation and objectification of women ... the law infers harm simply from that degradation and objectification." ${ }^{, 72}$

In Pelletier, the appellant at trial was fined 100 dollars for operating a bawdy house in Quebec; however, the Supreme Court was to determine whether the lap dancing occurring within the strip club constituted an indecent act. Writing for the majority, Justice Arbour determined that the trial judge carefully considered "all relevant factors in analyzing the standard of tolerance" coupled with the "nature and character of the touching that took place

Jochelson et al, Criminal Law and Precrime, supra note 4 at 45.

Tremblay, supra note 60 at 970.

Ibid at 969.

Ibid at 970 [emphasis added].

Mara, supra note 61 at 648 [emphasis in original].

Ibid at 647.

Ibid at 651 .

Ibid. 
between the dancers and the police, and with the circumstances prevailing in the cubicle." 73 Indeed, the dance occurred in a private cubicle with the curtain partly opened, and the strip club allowed patrons to touch the dancers for ten dollars. ${ }^{74}$ While the trial judge did not have the benefit of either Tremblay or Mara to rely on in his verdict, Justice Arbour agreed with the trial judge and indicated that "in the present case it does not appear that the judge committed an error of law in his assessment of the standard of tolerance" nor did it cross the line on what the community would tolerate. ${ }^{75}$ In effect, the Supreme Court majority upheld the appeal and restored the trial judge's acquittal.

Finally, and most significantly, Kouri and Labaye concerned charges against the proprietors of establishments alleged to be bawdy houses. As defined under section 197 of the Criminal Code ${ }^{76}$ a common bawdy house is a "place that is kept or occupied, or resorted to ... for the purpose of prostitution or for the practice of acts of indecency."77 While Labaye is discussed further below, it is important to briefly mention the case here in relation to Kouri, Labaye's companion case. Counsel for both Mr. Labaye and Mr. Kouri argued that acts occurring in these establishments were not indecent under the criminal law, and as such, both cases turned on the statutory interpretation of "indecency." While neither case involved a constitutional challenge of the then bawdy house provisions of the Criminal Code, the cases differentiated mainly by the degree to which their activities were publicly accessible. The issue in Labaye was whether activities of a private members' sex club were indecent under the Criminal Code, while the issue in Kouri was whether acts occurring at Coeur à Corps, a non-members' club, constituted criminal indecency. ${ }^{78}$

In Kouri, Justice Otis, in the Court of Appeal of Quebec majority decision, quashed the trial court's bawdy house conviction. The Court did so on the basis that "sexual morality is, first and foremost, the result of responsibility which human beings assume towards [themselves]" and that "Canadian society, which is pluralist and tolerant, does not condemn sexual modes of expression [that] are not a source of social harm" and are not offensive. ${ }^{79}$ The Court of Appeal's decision was reaffirmed by the Supreme Court of Canada in its majority decision, as it drew upon the Labaye harms-based test to determine that not only did the club ensure appropriate measures were taken to secure the acts from public view, ${ }^{80}$ but there was "no evidence of inducing anti-social attitudes through demeaning, abusive or humiliating treatment of any individual or group," psychological harm to the participants" within Coeur à Corps. ${ }^{82}$

Labaye holds the most significance in terms of harms-based tests, as the Labaye test ultimately abandons a consideration of the community's ostensible tolerance for harm and establishes a shift towards objective harm, which, as we have argued elsewhere, was no more

Pelletier, supra note 62 at para 1.

Ibid.

Ibid at para 2 .

Referred to as section 197 prior to amendment of the provision.

Supra note 2, s 197.

Kouri SCC, supra note 15 at paras 1-2; see also Craig, "Laws of Desire," supra note 4 at 358.

$R v$ Kouri (2004), 191 CCC (3d) 42 (Que CA) at para 51.

Kouri SCC, supra note 15 at paras $15-20$.

Ibid at para 22 .

Ibid at para 23 . 
than a shift towards political abstraction. ${ }^{83}$ While proponents of the Labaye test argue that the Labaye decision is a move towards a more complex, nuanced, and (arguably) just approach to sexual expression and materials, in practice this abstraction is the potential evidentiary vacuum Labaye creates and which persists to this day.

\section{The Labaye Era (2005-Present)}

In Labaye ${ }^{84}$ the accused was charged with keeping a common bawdy house for the practice of acts of indecency under section 210(1) of the Criminal Code. The accused operated the l'Orage swingers club, a club in Montreal that permitted couples and single people to meet each other for group sex. The Supreme Court "largely analyzed the case under the Canadian obscenity doctrine as it had evolved from Hicklin through Butler." 85 The majority decision, written by Chief Justice McLachlin, held that the community standards of tolerance test, which must be violated in order to establish a charge of indecency, was to be replaced with a harms-based test. In this decision, the Supreme Court determined that the former community standards of tolerance test would be impossible to apply objectively. The Supreme Court indicated:

\footnotetext{
In a diverse, pluralistic society whose members hold divergent views, who is the "community"? And how can one objectively determine what the community, if one could define it, would tolerate, in the absence of evidence that community knew of and considered the conduct at issue? In practice, once again, the [community standards of tolerance] test tended to function as a proxy for the personal views of expert witnesses, judges and jurors. ${ }^{86}$
}

The Supreme Court in Labaye retired the community standards of tolerance of harm test set out in Butler and shifted towards a harm-based approach. ${ }^{87}$ The Supreme Court reviewed the basic tenets of harm from Butler, noting that harm, in this context, was conduct which "predisposes persons to act in an anti-social manner." ${ }^{88}$ Anti-social conduct was that conduct "which society formally recognizes as incompatible with its proper functioning. The stronger the inference of a risk of harm the lesser the likelihood of tolerance." 89

For a finding of indecency, the majority proposed analyzing the nature of the harm first. Three types of harm emerged from the case law: "(1) harm to those whose autonomy and liberty may be restricted by being confronted with inappropriate conduct; (2) harm to society by predisposing others to anti-social conduct; and (3) harm to individuals participating in the conduct." 90 Though these categories of harm were not closed, the majority noted that the past obscenity and indecency cases fell within them. The second step of the test would be to determine if the quantum of harm was sufficient to interfere with the proper functioning of society, keeping in mind that the values fundamental to society were rooted in constitutional values, or similar legislative and rights-based rationales like equality, autonomy, and

Jochelson \& Kramar, "Governing Obscenity \& Indecency,” supra note 11 at 306.

Supra note 1 .

Yan, "Freedom of Expression and Obsenity," supra note 17 at 380.

Labaye, supra note 1 at para 18.

Ibid at para 21 .

Ibid, citing Butler, supra note 39 at 485.

Ibid [emphasis added].

Ibid at para 36. 
liberty. ${ }^{91}$ Therefore, one must assess whether "the harm or risk of harm is of a degree that is incompatible with the proper functioning of society." 92

While noting that harm is more demonstrable than community standards, the majority was compelled to develop a modified theory of harm to resolve the limitations of the community standards of tolerance test. However, the majority merely encouraged an "incremental" reassessment of this test:

Developing a workable theory of harm is not a task for a single case. In the tradition of the common law, its full articulation will come only as judges consider diverse situations and render decisions on them. Moreover, the difficulty of the task should not be underestimated. We must proceed incrementally, step by cautious step. $^{93}$

Since the case at hand only required "the further exploration of what types of harm, viewed objectively, suffice to found a conviction for keeping a bawdy house for the purposes of acts of indecency," an incremental reassessment rather than a complete reworking of a theory of harm was warranted..$^{94}$ It is important to note, however, that since adjudication of the anti-prostitution regime in the Bedford case and Parliament's response, the term bawdy house is only defined by the circumstances of acts of indecency and not acts of prostitution, hence making the Labaye harm test the sole determinant of whether a bawdy house offence has occurred. ${ }^{95}$

Thus, the Supreme Court replaced the Butler test. Per the Supreme Court in Labaye, the new objective harms-based test would be grounded in values recognized by our Charter and other Canadian fundamental laws which underpinned the need to protect society from harm. ${ }^{96}$ While the Supreme Court recognized that value judgments cannot be avoided in public decency standards, trial judges must ensure their decisions are as objective as possible:

Value judgments in this domain of the law, like many others, cannot be avoided. But this does not mean that the decision-making process is subjective and arbitrary. First, judges should approach the task of making value judgments with an awareness of the danger of deciding the case on the basis of unarticulated and unacknowledged values or prejudices. Second, they should make value judgments on the basis of evidence and a full appreciation of the relevant factual and legal context, to ensure that it is informed not by the judge's

Ibid at paras 56-57. Per Chief Justice McLachlin:

Incompatibility with the proper functioning of society is more than a test of tolerance. The question is not what individuals or the community think about the conduct, but whether permitting it engages a harm that threatens the basic functioning of our society. This ensures in part that the harm be related to a formally recognized value, at step one. But beyond this it must be clear beyond a reasonable doubt that the conduct, not only by its nature but also in degree, rises to the level of threatening the proper functioning of our society.... If the harm is based on the threat to autonomy and liberty arising from unwanted confrontation by a particular kind of sexual conduct, for example, the Crown must establish a real risk that the way people live will be significantly and adversely affected by the conduct. The number of people unwillingly exposed to the conduct and the circumstances in which they are exposed to it are critical under this head of harm.

Ibid at para 26 [emphasis added].

Ibid at para 27.

Criminal Code, supra note 2, s 197: "common bawdy-house means, for the practice of acts of indecency, a place that is kept or occupied or resorted to by one or more persons."

Labaye, supra note 1 at para 30. 
subjective views, but by relevant, objectively tested criteria. Third, they should carefully weigh and articulate the factors that produce the value judgments. By practices such as these, objectivity can be attained. ${ }^{97}$

In addition, to determine whether the alleged harm rose to the level of incompatibility with society's proper functioning, the Supreme Court suggested that, in most cases, expert evidence would be needed to establish actual harm; if the Crown relies on establishing risk of harm rather than actual harm, such evidence may be absent. This was largely the focus of the second phase of the Labaye analysis: whether the quantum of harm rises to the level of incompatibility with society's fundamental values as exemplified by their delineation in constitutional or related documents; that is, whether the quantum is sufficient to harm political values. ${ }^{98}$

With this new test, the Supreme Court in Labaye determined that the liberty and autonomy of members of the public were not affected by the l'Orage swingers club, and sex in secure locations was deemed compatible with the proper functioning of society. As the Supreme Court indicated, "[c] onsensual conduct behind code-locked doors can hardly be supposed to jeopardize a society as vigorous and tolerant as Canadian society," 99 as the autonomy and liberty of members of the public "was not affected by unwanted confrontation with the sexual conduct in question." 100 Only those who were already disposed to swinging participated at l'Orage, which was a matter guaranteed by the club's membership fees, locked doors, and screening meetings with potential club members.

According to the Supreme Court in Labaye, no one was coerced into sex, no one was paid for sex, and no one was treated as a "mere sexual object for the gratification of others." ${ }^{101}$ In sum, protecting society from harm continues to be a central feature of law. However, the nature of harm required to sustain an indecency charge remains somewhat unclear, because harm as articulated in Labaye can clearly invoke harms to political values. Sustaining and guarding society's "proper functioning" presumes a moral order based on consensus "which embraces law as a means of imposing and delineating limits on actions" through, at least in some cases, unsubstantiated risks of harm. ${ }^{102}$ However, we must query whether this pattern continues in adjudications since Labaye, a focus to which we now turn.

\section{A Word on Methods and Post-Labaye APPLiCATIONS OF HARMS-BASEd TESTS}

The project we decided to undertake in the coming pages is a slightly unusual approach for legal scholarship. While we studied the post-Labaye applications of the harm test, we began to notice its use outside of the indecency and obscenity context. Indeed, its use outside these quarters was more common than its use in obscenity and indecency adjudications. The challenge was then to understand these shifts in the use of Labaye from a more theoretical perspective since its most common use was in obiter. Our analysis, then, is less concerned

Ibid at para 54 .

Ibid at paras 60-61.

Ibid at para 71; Labaye's sister case, Kouri SCC, supra note 15, applied the test to a less secure night club setting that took less precaution in respect of loss of autonomy and still found no "harm."

Labaye, ibid at para 66.

Ibid at para 67.

Jochelson et al, Criminal Law and Precrime, supra note 4 at 47. 
with strict legal doctrine and more with the way courts are deploying the harm test more generally. Therefore, our goal in our exploration of the decision is more than merely doctrinal (though doctrine is of profound importance). Rather, the socio-political implications of the courts' treatments of Labaye interests us as well. What then distinguishes the sociolegal textual analysis of case law from the legal doctrinist? The legal scholar mines the text of a legal decision looking for disposition effects. She first desires to see who won the case on the legal issues. Second, a legal scholar will examine the reasoning of the case looking for philosophies underpinning the disposition in order to ascertain what reasoning will be of precedential value for future cases. The legal scholar is concerned with the future impacts of judicial prose on future cases and will be principally concerned with those aspects of judicial reasoning that impact on the precedent. Yes, the project is textual, but its focus on precedent is what makes it doctrinal - a study of what is, and what is to become of, the law. Traditional legal analysis of doctrine (doctrinal analysis) is limited by its reliance on underlying assumptions that serve to undergird the ontological structure of the law.

In contrast, our methodology, drawing from sociological critical legal studies, complements doctrine and its "professional" experience by questioning underlying assumptions. ${ }^{103}$ Within a doctrinal position, a judge's decision that, for example, the Charter supersedes the common law would set a case precedent and resolve the legal tension. However, from the critical perspective, this underlying conflict represents an "attempt to create coherence out of the competing and contradictory social influences and arguments which animate them."104 Just because the Supreme Court has ruled on which police procedures are legal does not preclude other social factors from contributing, challenging, or contradicting that ruling. In other words, though the ruling may be singular, both the precedents and outcomes are plural. Moreover, the outcomes spur a large number of social processes that go beyond the state. A person may be sentenced to prison or probation or community service, subjected to a peace bond, designated a dangerous offender, or required to provide a DNA sample - each outcome instantiates relationships with a large number of state and non-state agencies. ${ }^{105}$ Our method is textual, but it seeks to explain the mechanics of how the law has come to the state we now find it in, to determine what that state is, and to query how else that state may have developed. It is unsurprising that a reader might view our work as doctrinal at first blush, but our motivating analytic is focused on a distinct prize.

As the Appendix makes clear, we identified 48 relevant cases implementing and citing Labaye since 2005. We only recorded cases where written decisions implementing or citing Labaye were reported on the CanLII database and the Lexis Advance Quicklaw platform. A search for cases citing "R v Labaye, [2005] 3 SCR 728, 2005 SCC 80" was made in all Canadian cases to determine how the judiciary would draw upon Labaye in the case at hand (and through noting up procedures). Such cases ranged from the inclusion of Labaye in a mere footnote to drawing upon the Labaye test in its entirety to determine whether actual or a significant risk of harm was raised. After taking into consideration multiple entries of the University Press, 1995) at 45; Roberto Mangabeira Unger, "The Critical Legal Studies Movement" (1983) 96:3 Harv L Rev 561 at 563. 
same case in the search, 48 cases were confirmed. Below we draw upon particular cases to address the themes of Labaye's application.

\section{FINDINGS}

Below we discuss our review of 48 cases, which explicate treatments of the Labaye decision. From our review, five significant thematic trends emerged in the case review process: (1) the use of Labaye as an appropriate approach to considering harm in non-sexual materials - such as political speech, constitutional law, administrative law, and sentencing law; (2) the use of Labaye as a barometer of harm, indicating sexual dynamism as well as objectivity in sexually explicit scenarios; (3) the use of Labaye as indicative of harms in crimes that are either "objectively serious" crimes or obviously serious in nature; (4) the use of Labaye as a means of determining impermissible societal and sexual risk of harm and its "risky" collateral effects; and (5) the use of Labaye and the difficulty of prosecuting bawdy house harms going forward since Labaye. In effect, our methodology does not examine these cases for precedent per se, but attempts to focus on the socio-political rationales in the plural and the discursive impacts the Labaye decision has upon notions of harm, sexual expression, and sexual conduct.

\section{LABAYE: DISCURSIVE REFLECTIONS IN Political Speech, Constitutional Law, Administrative LaW, AND SENTENCING LAW}

Upon further examination of the sample of cases, we find varied usages of Labaye from the judiciary. This is unsurprising since the Labaye case was a landmark case on the adjudication of indecency and obscenity law. The cases seem to view the Labaye test as a credible move towards a more nuanced approach to sexual expression and materials, and indicate in their decisions the contextual nature of finding guilt in cases of indecency and obscenity; on some occasions, the use of Labaye analytics is drawn upon in situations of speech that do not involve sexual content and even in the constitutional context of free expression jurisprudence. This is significant because, on such occasions, the test is used as a proxy for assessment of harm outside of the circumstances of the actus reus of obscenity and indecency offences. The test then becomes a progenitor of harm in other, unintended contexts. To be clear, the move in such cases is more discursive than precedential. The use of Labaye is subtle, in that it becomes persuasive of harms as opposed to transplanting itself as the legal test for harm in such cases.

For example, in Greater Vancouver Transportion Authority v. Canadian Federation of Students - British Columbia Component, ${ }^{106}$ the issue at hand was whether the appellant transit authorities infringed upon the freedom of expression of the Federation when they refused to post political advertising on their operating public transit vehicles. Four main issues were in dispute: (1) the question of whether companies operating transit systems in Vancouver and elsewhere in British Columbia are subject to the Charter; (2) if so, whether the contested policies adopted by the transit authorities infringe the respondents' right to freedom of expression; (3) if so, whether each of these policies constitute a "rule of law," 
setting reasonable limits within the meaning of section 1 of the Charter; and (4) whether these policies can be the subject of a declaratory judgment based on section 52 of the Constitution Act, 1982. ${ }^{107}$ Writing for the Supreme Court majority, Justice Deschamps drew upon Labaye to recognize that in the criminal law context, what is indecent in one place may not be indecent in a more private location. ${ }^{108}$ In terms of the Charter's section 1 jurisprudence on freedom of expression (that is, the phase of constitutional analysis where government bears the onus of justifying infringement of a constitutional right), "location matters, as does the audience.... [T] he likelihood of children being present matters, as does the audience's ability to choose whether to be in the place."109 As Justice Deschamps indicated:

I have some difficulty seeing how an advertisement on the side of a bus that constitutes political speech might create a safety risk or an unwelcoming environment for transit users. It is not the political nature of an advertisement that creates a dangerous or hostile environment. Rather, it is only if the advertisement is offensive in that, for example, its content is discriminatory or it advocates violence or terrorism — regardless of whether it is commercial or political in nature - that the objective of providing a safe and welcoming transit system will be undetermined. ${ }^{110}$

It "seems right to suggest that citizens are expected to put up with some degree of controversy"; the difficulty, however, lies in determining "a principled and just distinction between what constitutes offensive advertisement on government-owned property and what are merely controversial advertisements on government-owned property."111 While the decision focused primarily on political advertising as that was what was at issue, the Supreme Court drew conclusions and made suggestions that could be problematized in the context of Labaye species of harms.

Nevertheless, the Supreme Court majority found that the transit authorities placed an unjustifiable limit on the respondent's political advertising on transit buses and the respondent's right to freedom of expression. ${ }^{112}$ However, just as interesting as its invocation of Labaye in a non-indecency and non-obscenity context was the Supreme Court's reliance on the community standard test as arbiter of tolerance for offensive speech (the test itself was codified in the policy but the Supreme Court did not problematize the concept as it had earlier in Labaye). It would appear the Supeme Court's concerns with the amorphousness of the test, as expressed in Labaye, will not stop invocation of the community standards of tolerance test in other analytical circumstances.

In R. v. Smickle ${ }^{113}$ the accused challenged the constitutionality of the mandatory minimum sentence against possessing a loaded firearm. While Justice Molloy did not draw upon Labaye to determine that the accused's application should be allowed, Labaye was relied

\footnotetext{
107 Ibid at para 12

108 Ibid at para 78

109 Ibid.

$110 \quad$ Ibid at para 76

111 Elaine Craig, "Section 2(b) Advertising Rights on Government Property: Greater Vancouver Transportation Authority, A New Can of Worms and the Liberty Two-Step?” (2010) 33:1 Dal LJ 55 at 73.

112 Greater Vancouver, supra note 106 at para 80.

1132012 ONSC 602 [Smickle].
} 
upon to underscore the difficulty in applying a subjective approach for defining what activities constitute "indecent" acts. ${ }^{114}$ Interestingly, the Justice draws an analogy between shifting sentencing mores in a constitutional context with shifting sexual mores in a criminal law context:

\begin{abstract}
It is interesting that of the nine criteria [for determining gross disproportion in the section 12 Charter-based constitutional adjudication of a sentence] noted by Professor Tarnopolsky, Lamer J. selected only those which import an objective assessment, rather than the "standards of decency" type of analysis that was largely featured in the early case law. This lends some support to the defence argument before me that Smith imposes an objective test for determining what is "cruel and unusual" [for section 12 of the Charter]. It is also consistent with the views expressed by the Supreme Court in other cases, e.g., the difficulty in applying a subjective approach for determining the "moral position" of the community on the death penalty ... and for defining what constitutes "indecency" on a charge of keeping a common bawdy house for the practice of acts of indecency.... In those cases, the Court has advocated an objective standard rather than undertaking an analysis of standards of tolerance in the community. ${ }^{115}$
\end{abstract}

Clearly, the Justice is drawing on the weighing of the constitutional conceptions of gross disproportion as analogous to Labaye harm calculi in the obscenity and indecency criminal law calculus. The purported objectivity of Labaye is apparently influential to harms across a variety of milieus. The Labaye calculus, and its attempts to objectify harm, are being used by judges as persuasive impeti to move other harm calculi towards objective assessments as well.

A similar recognition was noted in The Canadian Centre for Bio-Ethical Reform v. South Coast British Columbia Transportation Authority. ${ }^{116}$ In this case, the petitioner (the Canadian Centre for Bio-Ethical Reform) sought to display a pro-life advertisement on respondents' buses in the Lower Mainland of British Columbia. The petitioner argued that freedom of expression includes the right to communicate controversial and unpopular messages which the majority of society may deem wrong or false and emphasized that bus riders are expected to put up with some controversy in Canadian society. Consequently, "the petitioner submitted that the respondent failed to properly balance the Charter guarantee of freedom of expression with its statutory objectives." 117 In essence, "the respondent's position was that it was permitted to refuse advertisements on the basis of their content," and that the Criminal Code constitutes a guideline compliant with the section 2(b) expression guarantee of the Charter. ${ }^{118}$ Given the inaccuracies of the advertisement's content ${ }^{119}$ coupled with the "psychological harm that the petitioner's advertisement would have on women and children riding its buses," 120 the respondent's decision to refuse to host the advertisement constituted a reasonable limit on the petitioner's freedom of expression rights. ${ }^{121}$ In effect, the overarching question for the Court was whether the respondent had the right to refuse the petitioner's request. Justice Leask drew upon the decision in Greater Vancouver (and cited

Ibid at para 44 .

Ibid [footnotes omitted].

2017 BCSC 1388 at para 17.

Ibid.

Ibid at para 37.

Ibid at para 34

Ibid at para 31 .

Ibid at para 37. 
the same passage from Labaye as Justice Deschamps had) to highlight the contextual nature of indecency. ${ }^{122}$ Justice Leask found that the respondent's decision to reject the petitioner's pro-life advertisements (which included graphic imagery of fetuses) on transit buses operating in the Lower Mainland of British Columbia was reasonable and appropriate. ${ }^{123}$ While the Court determined that the respondent had infringed upon the petitioner's freedom of expression "rights in denying publication of their advertisement," 124 Justice Leask indicated that the infringement was reasonable:

[T] he advertisement could potentially cause psychological harm to children, and, to that extent, its rejection for publication was reasonable ... I find that the advertisement could cause psychological harm to women. While women are not as vulnerable to graphic imagery as children, clearly comparing women who have had abortions to "killers" is content that many members of the general public, especially women, would find disturbing. 125

The decision nicely encapsulates the unintended discursive effects of the Labaye three tiers of harm application to speech not squarely within the indecency and obscenity criminal context. Might the Supreme Court be developing a jurisprudence of harm in all cases of offensive speech that relies on the Labaye calculi? The use of Labaye harm calculi in these instances is important because it shows the potential of the test to leap from merely being a test for establishing actus reus of indecency and obscenity to a discursive construct that is explicative of harm in other public law arenas.

\section{LABAYE AS A DISCURSIVE BAROMETER OF SEXUAL DYNAMISM IN CANADIAN SOCIETY AND AS A LANDMARK OF OBJECTIVITY}

Furthermore, some courts, in the sample we identified, drew upon Labaye to acknowledge the changes to sexual freedoms in contemporary Canadian society. Often these strands of judicial prose are found in obiter treatment of Labaye. For example, in R. v. J.R., ${ }^{126}$ Justice Ducharme found that the two accused (each charged with one count of sexual assault and one count of gang sexual assault) were guilty of sexual assault and not guilty of gang sexual assault against the complainant. In rendering this verdict, Justice Ducharme referenced Labaye in a footnote to indicate that the Justice had made findings of fact "based on the evidence before [them] uninfluenced by [their] own sexual mores"; furthermore, the Justice, noting Labaye, recognized "that there are some people who do participate willingly in such multi-partner sex" in society; however, in the case before the Court this was not the situation. $^{127}$

In $R . v . D M,{ }^{128}$ the accused was charged with ten sexual offences against his stepgranddaughter. In rendering a verdict of not guilty upon the accused, Justice Morgan drew upon Labaye to indicate that the Justice felt "compelled to note that societal mores with 
respect to sexuality are today rather promiscuous" and that Court did not wish "to pass judgment on society, and certainly not to excuse anti-social or harmful conduct - especially not conduct directed toward children. But for better or for worse, sex talk and sexual imagery permeates mainstream culture." 129

Indeed, references to Labaye were also recorded in the courts acknowledging wider societal shifts and concerns. For example, in the trial court decision of $R$. v. Levkovic, the applicant challenged the constitutional validity of section 243 of the Criminal Code, which pertains to the offence of the concealing of a child's dead body. ${ }^{130}$ The applicant argued that the sole legislative purpose of the provision was to further stigmatize, marginalize, and "criminally punish women "who bore illegitimate or "bastard" children" and that the vague language of the provision was so overbroad as to overshoot legitimate objectives of criminal legislation. ${ }^{131}$ Drawing upon Labaye, Justice Hill recognized "the reality of victimization" to both infants and their mothers in suspicious infant deaths ${ }^{132}$ and determined that the applicant had established that the impugned words of the provision were "unconstitutionally vague and therefore inconsistent with the principles of fundamental justice"; this constitutional finding was ultimately overturned by the Supreme Court, but we study the trial decision to observe the way Labaye is influencing understandings of sexual harms apart from the final constitutional decision in this case. ${ }^{133}$ The Labaye precedent was used by Justice Hill to infer that an analysis of harms requires vigilance by courts as to determining victimization and to note that some conduct might be apprised of multiple species of harms at the same time. Thus at the trial court, Labaye was used as a means of identifying harm through identifying victimization and noting that sometimes harms are complex and multivalent, and operate in conflicting fashions.

Langevin c. TH Construction Inc. comprised three separate applications that shared a common thread of factual evidence in the same hearing. ${ }^{134}$ First, the plaintiff, Ms. Langevin, brought about claims for damages done to her property by the respondent while the respondent attempted to implant a septic tank system on the plaintiff's property. The plaintiff claimed that the work done by this company "was not done according to the rules of art," having unnecessarily cut down a dozen trees on her property. ${ }^{135}$ The plaintiff had to carry out a soil characterization study by JMB Technical Services and retain the services of a different septic tank company to finish the work on her property. TH Construction Inc., the respondent, made a counterclaim for abuse of law, demanding that the plaintiff should pay for the soil characterization study and the installation of the septic tank and denied any true damage to the property, ${ }^{136}$ adding that the plaintiff's claims were "grossly exaggerated."137 Second, the plaintiff claimed to have acquired a parcel of land and wanted ownership settled

\footnotetext{
$129 \quad$ Ibid at para 59.

2008 CanLII 48647 at para 1 (Ont SC).

Ibid at para 2 .

Ibid at para 140 .

Ibid at para 214. Ultimately the Supreme Court dismissed the constitutional arguments of the accused in $R v$ Levkovic, 2013 SCC 25.

2016 QCCQ 14897 at para 1.

Ibid at para 52 [translated from French].

Ibid at para 55 .

Ibid at para 56 [translated from French].
} 
by the Court. ${ }^{138}$ The respondent made a counterclaim in that regard. ${ }^{139}$ For our purposes, and finally, the plaintiff claimed for damages citing that she and her co-plaintiff were victims of inappropriate and defamatory remarks as to their sexual practices that the defendant or respondent made about them. ${ }^{140}$ The respondent indicated that said remarks in question were not denied and were true, but that it was his cousin who conveyed these comments publicly. ${ }^{141}$

In his verdict, Justice Brunelle sided with the lead plaintiff on the substance of the main claims. For the claim of defamation, which focused upon whether the defendant or respondent was allegedly telling people that the couple (that is, the two plaintiffs) was "adept at swinging,"142 Justice Brunelle drew upon Labaye to underscore that the relationship between two of the plaintiffs had gone from a close friendship to a love affair, and while the plaintiffs failed to convince the Court that they had been defamed on a balance of probabilities, ${ }^{143}$ the Court noted that sexual practices conducted by consenting adults "are at the very heart of the right to privacy" and that privacy should be upheld where possible. ${ }^{144}$

Here we see, in a non-criminal context, the influence of the findings of lack of harm in Labaye as to swinger's clubs that sets up a discursive corollary - if there is no harm in sexual conduct, the suggestion of a reasonable entitlement to privacy in sexual life is surely deserved. Further, sexual practices that were once considered on the fringes ought in theory to be subject to those privacy protections, even in the context of a purely civil matter. The discursive effect of Labaye in this case seems to be greater entitlement in the civil context to privacy regarding sexual behaviours that were once seen as moral outliers.

Finally, in R. v. LaPage, the issue was whether the accused had committed the offence of gross indecency ${ }^{145}$ against the complainant in the summer of $1970 .{ }^{146}$ Justice Molloy draws

$138 \quad$ Ibid at para 59.

$139 \quad$ Ibid at para 57.

$140 \quad$ Ibid at para 62.

$141 \quad$ Ibid at para 64.

142 Ibid at para 182 [translated from French].

$143 \quad$ Ibid at para 189.

144 Ibid at para 198 [translated from French].

1452014 ONSC 5855 [LaPage]. However, the offence of gross indecency has long been since repealed. In 1984, the Committee on Sexual Offences Against Children and Youths made a number of recommendations to Parliament, of which one included the repealing of the gross indecency provision in the Criminal Code. In 1985, a report from the Special Committee on Pornography and Prostitution made a similar recommendation. Finally, in 1986 the then Canadian government introduced legislation that repealed the offence of gross indecency. For a further review of the legislative and historical development which led to the repeal, see John Nicol, "Legislative Summary of Bill C-32: An Act Related to the Repeal of Section 159 of the Criminal Code" (2017), online: <https://lop.parl.ca/sites/ PublicWebsite/default/en_CA/ResearchPublications/LegislativeSummaries/421C32E>. LaPage, ibid at para 1 . As the trial judge explained at paras 20-25 [footnotes omitted]:

The facts underlying the alleged crime took place 44 years ago. It is well-settled that the applicable law is the law that was in force at that time. At the time of this incident in 1970, WG had achieved the age required for legal consent to sexual intercourse. WG had the capacity to consent to the sexual conduct that took place, and it is conceded by all that he did consent to it. This was not a sexual assault and, indeed, Mr. LaPage is not charged with sexual assault.

Rather, Mr. LaPage is charged with the offence of committing an act of gross indecency, something that has not been a crime in Canada since the mid-eighties. In 1970, however, it was a crime. The relevant section of the Criminal Code stated:

s. 149. Every one who commits an act of gross indecency with another person is guilty of an indictable offence and is liable to imprisonment for five years.

In 1969, the legislation was amended to provide certain exceptions to the gross indecency offence, e.g. exempting acts committed in private between a husband and wife and between two persons each of whom is 21 years of age or more. "Gross indecency" was never a defined term in the 
upon Labaye to indicate that judges should always strive to be as objective as possible in adjudication:

In approaching this task, I must determine whether the actions of Mr. LaPage on the date in question constitute a "very marked departure" from the "decent conduct expected of the average Canadian in the circumstances." Clearly, the standard to be imposed is what was considered to be "decent conduct" in Canada in $1970 \ldots$... How am I supposed to know that? No evidence was presented with respect to the social and sexual mores of average Canadians in $1970 \ldots$. Given the substantial period of time that has elapsed in this case, expert evidence would be required to establish the standards of public decency and sexual mores in $1970 .^{147}$

Many of the details between the accused and the complainant had been made unclear "[w]ith the passage of time." 148 Justice Molloy dismissed the criminal charge. ${ }^{149}$

However, the judge also noted the importance of Labaye in the adjudication of indecency:

In Labaye the Supreme Court of Canada noted the difficulty in determining whether impugned conduct is merely immoral, as opposed to criminal. The Court emphasized the need for this determination to be made objectively, rather than based on the subjective moral code of any particular decision-maker ... the Supreme Court recognized that value judgments cannot be avoided in determining public decency standards, but offered guidance for trial judges for making such decisions as objectively as possible. ${ }^{150}$

The Court's reluctance to foist morality onto its verdict and to hold to standards of objectivity in its findings suggests a discursive legacy of Labaye as moving courts to assessment of harm as both objective and based on normativity. It is of course that same normativity that interestingly allows for shifts in conceptions of harm over time to instantiate and to call into question the objective underpinnings of the test.

In sum, we see how cases vary in their extent of including Labaye into courts' varied adjudications. From a mere reference to drawing upon the Labaye test in its entirety, the harms-based test provides a modern way for the judiciary to determine whether actual or a significant risk of harm was raised to the level of impacting the proper functioning of society. The courts struggle to see the harms, whether in the civil or criminal context, as objectively constituted. This constitution sits in almost constant tension with the same courts' understanding that sexual mores have changed and that this context will alter objectivity. The balancing of objectivity with shifting sexual dynamism in context from a logical perspective has striking parallels to the pre-Labaye construct of community standards of tolerance of harm - itself a test that was supposed to be objectively held by the judge while at the same time considering the social barometer of the times. Less clear is what advantage this

Criminal Code. However, it is defined in the case law as being "a very marked departure from the decent conduct expected of the average Canadian in the circumstances". The case law also establishes that this is an objective test. The surrounding circumstances must be taken into account, including the relative ages of the participants, the nature of their relationship, and whether there was consent. 
dynamism has in the civil, or non-obscenity and non-indecency, realm, where the nature of Labaye-style harms are not inherently constitutive of liability or guilt under other criminal charges.

\section{X. "ObJectively Serious" Crimes OR OBVIOUSLY SERIOUS CRIMES}

A significant theme which arose from the cases we looked at was the use of Labaye by the judiciary to examine offences which would be abhorrent to Canadian social morality. ${ }^{151}$ In most cases, this occurred in the context of child pornography or exploitation of children.

In Cawthorne, Chief Military Judge Dutil was to determine whether the accused should be convicted of his actions — namely the accessing and possessing of child pornography while he was off-duty in Pearl Harbour. In Paquette, the accused had accepted and pleaded guilty to the charges of accessing child pornography and engaging in conduct to the prejudice of good order and discipline, and Military Judge Gibson was to determine the appropriate and just sentence for the accused. Both Ordinary Seaman Cawthorne and Corporal Paquette were sentenced to have their bodily samples on record for forensic DNA analysis as well as registered in the sex offender registration system, ${ }^{152}$ sentences which have become more prominent tools for law enforcement. Interestingly, both analyses by the military Court in Cawthorne $e^{153}$ and Paquette ${ }^{154}$ drew upon the same particular Labaye passage to recognize how the Supreme Court sanctions those offences in Canada which are "objectively serious" and would gravely offend Canadian society:

According to contemporary Canadian social morality, acts such as child pornography, incest, polygamy and bestiality are unacceptable regardless of whether or not they cause social harm. The community considers these acts to be harmful in themselves. Parliament enforces this social morality by enacting statutory norms in legislation such as the Criminal Code. ${ }^{155}$

To be clear, here the Court is not merely rotely applying a direct quote from Labaye to support the view that child pornography offences are abhorrent. Rather, the judicial decision is a careful consideration of rhetoric and reasoning that packages history, text, and context together. Unfortunately, we must be mindful that the justices in these cases draw upon a particular Labaye quote with an eye towards how social harm is to be perceived - or, like the community standards of tolerance test, at least how they themselves subjectively see abhorrence within sanctionable activities.

Rv Cawthorne, 2014 CM 1014 [Cawthorne]; Rv Paquette, 2014 CM 2014 [Paquette]. These cases went through the military court system, which is separate from the civilian court system in Canada. The military justice system in Canada has a two-tiered tribunal system. Less serious offences are tried in a summary trial, while more serious offences are tried in a court martial. Courts martial are presided over by military judges, and if the accused person is convicted, the military judge imposes the sentence. For a further review, see Government of Canada, "Military Law Reports and Publications" (2018), online: $<$ www.forces.gc.ca/en/about-reports-pubs-military-law/court-martial-system.page> . 
Similarly, while the sample search did not produce any results of bestiality or incest cases actually drawing upon Labaye, it remains certain that many of the courts that did draw upon Labaye recognized that violations of fundamentals of Canadian social morality would not be tolerated by the judiciary. These adjudications make clear that despite the Labaye application of categories of harm, when it comes to the second category of harm - harm to society by predisposing others to anti-social conduct — some courts are still putatively thinking of this arm of the Labaye test as apprised of Butler harms. That is, some judges may still believe that the three categories of Butler harms still inform the second category of harm in Labaye: (1) explicit sex with violence is harmful, (2) explicit sex without violence but which subjected people to treatment that was degrading or dehumanizing may be harmful when the risk of harm is substantial, and (3) explicit sex without violence that was neither degrading nor dehumanizing that did not involve children will not be harmful. Clearly, some expression is so offensive that its mere existence is harmful based on the severe risk the material poses. This is likely the alleged quantum of harm that the Supreme Court in Labaye noted when it wrote:

\footnotetext{
Where actual harm is not established and the Crown is relying on risk, the test of incompatibility with the proper functioning of society requires the Crown to establish a significant risk. Risk is a relative concept. The more extreme the nature of the harm, the lower the degree of risk that may be required to permit use of the ultimate sanction of criminal law. Sometimes, a small risk can be said to be incompatible with the proper functioning of society. For example, the risk of a terrorist attack, although small, might be so devastating in potential impact that using the criminal law to counter the risk might be appropriate. However, in most cases, the nature of the harm engendered by sexual conduct will require at least a probability that the risk will develop to justify convicting and imprisoning those engaged in or facilitating the conduct. ${ }^{156}$
}

While the military adjudications above suggest the obviousness of some crimes makes proof of harm less important and can contribute to an aggravating factor in sentencing, other courts posit similar conduct as inherently risky — a matter we discuss in the next section.

\section{SeXual Risk: The Significance of \\ (Risk OF) HARM AND Discursive COLlateral EFFects — TO INDECENCY AND BEYOND}

As noted above, some conduct is so risky that the application of the Labaye test will ask for less in the way of empirical proof to demonstrate that harm has been proven. While the Supreme Court in Labaye gave the example of a terror attack, in practice, risk is assessed in less dire circumstances.

In Roberts (Re), the issue at hand was whether the renewal of the liquor licence for a cabaret providing adult entertainment would interfere "with the quiet enjoyment of neighbourhood properties." ${ }^{157}$ On a balance of probabilities, the Nova Scotia Utility and Review Board found that a significant risk of harm would occur as the opening and operation of the Sensations cabaret and the "disturbing incidents" alluded to in the evidence — such as an increase in "noise, persons urinating on the front of houses, women being solicited for 
sex or asked to expose their breasts, women being followed by slow moving cars" - are "attributable to persons who are customers leaving Sensations, going to Sensations, or attracted to the neighbourhood for similar reasons." ${ }^{158}$ In effect, the Board granted the liquor licence with conditions, the primary condition being that the adult entertainment privileges the cabaret held would be terminated. The risk of such exposure would create obvious harms in terms of public exposure. Here, links to old community standards of tolerance of harm test reasoning seems clear. Clearly, the legacy of the community standards test is germane in the regulatory licencing context, even in cases like this one, where the Labaye test is invoked.

In R. c. Colalillo, Mr. Colalillo was charged with three counts of first-degree murder; however, the accused had died in the early morning hours prior to his appearance in court, and all criminal proceedings pending against him were terminated. ${ }^{159}$ The issue before Justice Cohen was to determine whether the Court should order a permanent publication ban on a series of letters written by the deceased accused, detailing graphic information about the accused's fantasies of murder, rape, and the sexual assault of women and children. ${ }^{160}$ Rather than drawing upon expert evidence, Justice Cohen decided that the letters, through the Labaye framework, should be banned from public view, as the Justice indicated that "unwilling viewers" would face an intolerable risk: "the risk of harm from the explicit content of these letters would be available here if a publication ban were not in effect."161 Justice Cohen was essentially using the "affronts to liberty" prong of the Labaye harm test to justify a publication ban, thereby further instantiating Labaye calculi into the realm of court procedure and openness. Justice Cohen contended that publication would reasonably expect to have a corrupting effect on public morality and hence implemented the publication ban. Here, Justice Cohen further justified the ban on the attitudinal change prong of the Labaye calculus. Interestingly, the Court's "I know it when I see it" approach to harm analysis harks back to the community standard of tolerance test, insofar that justices imputed their own knowledge of morality, irrespective of empirical evidence to suggest otherwise, as Justice Cohen did. Furthermore, Justice Cohen's decision is still plausible under the risk of harm evidentiary exception when the Court in Labaye noted that " $[\mathrm{t}]$ he more extreme the nature of the harm, the lower the degree of risk that may be required to permit use of the ultimate sanction of criminal law."162 Interestingly, the test in this case impacted a decision to ban publication.

In $R$. c. Desmarais, the accused was charged for acts of indecency in front of a child. ${ }^{163}$ In his analysis, Justice Provost drew upon Labaye to suggest that, although the accused was intoxicated, his intention was clearly to frighten the girl by exposing his penis to her. Justice Provost indicated that no expert evidence was necessary to demonstrate that the accused's actions were indecent and "undermine[d] the physical and psychological integrity of children" in a properly functioning society. ${ }^{164}$ While few would question the severity of this conduct, it would seem that this is the type of risky behavior that would be akin to the 
Labaye terror attack scenario - one which obviates the need for proof of quantum of harm. Such cases illustrate the obviousness of the harms in circumstances of exposed genitalia, especially when children are confronted or at risk of being confronted. The assessment seems to draw upon both the harm evidentiary exception discussed above, but also on the basis of the special protection put in place for child victims under the Butler harm tiers, located in the attitudinal change prong of the Labaye test.

Similar corrupting and "risky" effects were also of issue for the judiciary in terms of those in the military serving overseas. Chief Military Judge Dutil in Cawthorne interestingly drew upon Labaye to note how the accused's participation in an international exercise outside of Canada was an aggravating circumstance to consider upon sentencing:

\begin{abstract}
The fact that most of the events that led to the charges took place while he was off-duty in Pearl Harbour does not diminish his responsibility. Committing service offences outside Canada inherently causes significant disturbances for the chain of command whether or not foreign authorities are involved in the investigative process or made aware of an incident.... The commission of criminal or disciplinary offences by service persons in operational settings outside Canada will inevitably occur on occasion, but they contribute to erod [ing] the state of readiness and discipline. The facts of this case indicate that some of the offender's brothers-in-arms were very troubled by the discovery of child pornography material found on his iPhone, and that has an impact on morale and discipline. ${ }^{165}$
\end{abstract}

Here, Chief Military Judge Dutil is placing the harm to others in the second prong of Labaye harms, where attitudinal change occurs in the form of damage to morale and discipline - a unique application of Labaye-style harms in the military sentencing context. Once again, Chief Military Judge Dutil inserts subjective understandings of moralism and discipline; and, without irrefutable proof to warrant further consideration, the Justice's reconstitution of harm appears less as a consideration for Labaye and more of what would be tolerated by a lone justice.

An interesting theme which arose from the cases we reviewed was whether certain materials were consumed or created in an exploratory or exploitative fashion. In $R$. $v$. Barabash, ${ }^{166}$ Donald Barabash and Shane Rollinson were charged with making child pornography, while Barabash was also charged with one count of possessing child pornography. At his home in Edmonton, Barabash had made both video recordings and still photographs of Rollinson engaging in sexual activities with the two complainants, the latter of whom were 14 years old at the time. The video recordings depict the complainants engaged in a variety of sexual activities with each other and with Rollinson. With the exception of one video, the recordings did not depict Barabash involved in any significant way in sexual activities; his role was "primarily restricted to one of an observer and recorder of these events." 167 Furthermore, all appeared to engage in sexual activity on a voluntary basis. Crack cocaine and perhaps marijuana were available although the two young women depicted were not visibly intoxicated in the recordings. ${ }^{168}$

Cawthorne, supra note 151 at para 18 [emphasis added].

2012 ABQB 99 [Barabash QB], rev'd 2014 ABCA 126 [Barabash CA], rev'd Rv Barabash, 2015 SCC 29 [Barabash SCC].

Barabash QB, ibid at para 9.

Ibid at para 10. 
One contested issue was whether the adult pair had "made" child pornography as the accused had advanced the "private use" defence. ${ }^{169}$ The victims were aged 14 at the time of the events, which was the age of consent at the time. The private use exception required a determination that the sexual activity depicted in recordings was lawful (which included an assessment that the content not be exploitative), that the recording of the sexual activity was also consensual, and that the recordings were held exclusively for private use.

Justice Thomas, at trial, drew upon Labaye to suggest that human sexual activity is diverse, and what is objectionable to one group "may be central to the identity of another."170 Justice Thomas' analysis provides a further understanding of the problems facing the court when it attempts to draw a line between exploration and exploitation:

[T] he Crown seems to argue that a sexual scenario of the kind that occurred in the Barabash residence cannot possibly be an healthy "self-fulfilment, self-actualization and self-exploration and identity" and is the very antithesis of two young persons building a "loving and respectful relationship." I see this suggestion as being that certain legal sexual activities, once recorded, are potentially child pornography because of their character... This proposition means the courts would need a way to review recorded legal sexual activity and somehow step into the context of the participants, and evaluate whether or not that activity meets [a] standard of exploration and identity, and built a non-abusive and non-exploitive relationship. Human sexual activity is diverse, and ... different sexual practices and depictions of those practices may have special meaning to different communities.

The problem with the Crown's approach is that the court has no good way to look at a recording of legal sexual activity and say, beyond a reasonable doubt, that the acts are of such a kind that cannot be healthy exploration and must instead be abusive and exploitive. I think a better approach is ... a court should not try to investigate the nature and character of the private sexual acts engaged in by young persons. ${ }^{171}$

In effect, Justice Thomas suggested that the Crown had not proven beyond a reasonable doubt that there was no "air of reality" to the "private use exception" defence and found the accused not guilty. ${ }^{172}$ Both the appellate court and Supreme Court of Canada disagreed with the trial judge's verdict and overturned the acquittals of the accused, principally because the private use exemption cannot apply in a situation of illegality and exploitation, the latter of which the trial judge did not adequately explore. ${ }^{173}$ It is important to note that the trial court was the first case that included Labaye in understanding the scope of "private use" materials, a subject which had not received much judicial commentary. ${ }^{174}$ The trial judge's decision in Barabash provided a further discussion of the healthiness of sexual activities and whether a court has the right to delineate certain sexual practices, conducts, and materials as explorative or exploitive. By drawing upon Labaye, Justice Thomas recognized the societal shifts in sexuality and went further to acknowledge, albeit controversially, that the bedroom may not be the place for the courtroom to adjudicate. Ultimately, the Supreme Court disagreed, finding the relationships and conduct obviously exploitative, illegal, and thus not

Ibid at paras $14-15$.

Ibid at para 230 .

Ibid at paras 228-30, 237 [citations omitted].

Ibid at para 278 .

See generally Barabash CA, supra note 166; Barabash SCC, supra note 166.

Barabash QB, supra note 166 at para 5. 
subject to the private use defence. The exploitative nature of the participants' relationships was suggestive of obvious harm and the Supreme Court saw no need to use Labaye in its adjudication of the matter.

In R. v. Katigbak, the Supreme Court was to determine whether the accused had a "legitimate" purpose in collecting images and video clips of child pornography to be used "to create an artistic exhibition that would present the issue of child exploitation from the perspective of the child." ${ }^{175}$ Chief Justice McLachlin and Justice Charron, co-authoring the majority Supreme Court decision, queried whether the activity of possessing this child pornography was intended to impose an undue risk of harm to children (as the Criminal Code stipulates) or if it was undertaken genuinely and in good faith by the appellant. In doing so, the Justices drew upon Labaye to examine whether the scales were tipped towards the imposition of a risk of harm:

The courts must strike a balance between the importance of freedom of expression and reducing the risk of harm to children.... The question is what degree of harm will be tolerated in the case of activity that has a legitimate purpose...

In our view, the Labaye interpretation is applicable in the present appeal. The words "undue risk of harm" set out in s. 163.1(6)(b) should be interpreted to mean a significant risk of objectively ascertainable harm as required by the law of obscenity, rather than the former "moral views of the community" approach. Relying on the moral views of the community would be as unworkable for child pornography offences as it is for obscenity charges. Reasonable people may hold sharply divergent views about the level of risk to young persons that should be tolerated as a result of artistic expression, or scientific research. Instead, the courts must ask whether the harm is objectively ascertainable and whether the level of the harm poses a significant risk to children. ${ }^{176}$

The Justices go on to state that Justice Lebel, dissenting, departed from the majority decision as the dissenting Justice believed that a balance should be struck between the specific harms of the offence and the inherent harms associated with child pornography, and that not providing this balance weighs in favour of courts expanding the sanctioning of an individual's possessing allegedly "risky" materials for artistic expression and educational merit:

The intervener Canadian Civil Liberties Association ("CCLA") submits that the risk of harm will only be "undue" if it is greater than the inherent risk posed by the possession of child pornography. It argues that if the courts find that all acts of possession of child pornography necessarily create an "undue risk of harm", they will effectively remove the defence Parliament intended for the administration of justice, science, medicine, education and art. To avoid this result, the CCLA submits that an "undue risk" must arise from something specific to the case, rather than the harms inherent to the offence charged (Factum, at para. 21). LeBel J. [in dissent] would adopt this approach. ${ }^{177}$

\footnotetext{
1752011 SCC 48 at para 2 [Katigbak].

$176 \quad$ Ibid at paras 64, 67 [emphasis in original].

177 Ibid at para 69.
} 
Notwithstanding this, the majority decision determined that while the defence of legitimate purpose (such as art) may be used in some cases, it would be incorrect to suggest such a balance between inherent and specific harms is warranted:

We agree that the two-step legitimate purpose/undue risk of harm defence must be read in a way that would allow it to apply in some cases... However, it is our view that no useful purpose would be served by drawing a distinction ... between harms that are "inherent" and those that are "specific" to the offence charged. All risks flowing from the commission of the offence must be considered in the "undue risk" assessment. We respectfully disagree with LeBel J. that this means that "the defence would inevitably fail" at the second stage of the analysis. ${ }^{178}$

Therefore, the Supreme Court majority in Katigbak determined that in terms of the charge of possessing child pornography, given the nature of the offence and the possible harms, a distinction between inherent and specific harms was unnecessary. The majority saw all risks emanating from the offence as potentially calculable towards the total harm suffered by children and society while Justice Lebel intended to qualify the harms considered in the offence itself and compare them to the case at hand. In the majority's view, the risk of harm was more substantial than the specific harms associated with the offence and the legitimacy of the activities Mr. Katigbak had laid out for the Supreme Court. Indeed, the passage of time between collection and the exhibition of the artwork was the circumstantial evidence the majority needed to believe that the accused's activities could be less than legitimate; it was this clarity that needed to be further sought in a new trial. Just as importantly, the majority imported the Labaye calculus into the assessment of child pornography offences. The conception that there is a blanket harm assumption for such offences is left for adjudication at a retrial. However, the majority seems clear that it will be open to the trial judge to assess risk so as to find harm in a given context in balance with the legitimate use defence to child pornography possession:

\footnotetext{
The determination of what the accused did and its consequences are questions of fact, to be decided on the basis of the evidence at trial. The trial judge must make findings of fact regarding the risks posed by the accused's activities, based on evidence as to the degree of the risk, viewed objectively. Expert evidence, while not always necessary, may assist in establishing a link between the actions of the accused and the creation of a risk of harm to young persons. As stated in Labaye, "[ $\mathrm{t}]$ he focus on evidence helps to render the inquiry more objective"... Having made these factual findings, however, the question of whether the risk is so significant that it is "undue" is a question of law.... The application of this legal standard to the facts is also a question of law. 179
}

The majority's approach seems to send a powerful message, that even in the context of fraught offences like child pornography related offences, returning to the community standards of tolerance of harm test will be analytically vulnerable. They direct the lower Court to phrase the harm calculus in the Labaye language of harm.

Another significant theme which arose from the sample was a reconsideration of whether expert opinion would always be necessary to determine if harm occurred. In Sheik, the 
Superior Court of Justice in Ontario interpreted the Labaye framework and its evidentiary requirements. ${ }^{180}$ The accused was observed by police in a well-lit high school parking lot, where the accused was in the company of a sex worker in the car. The accused's penis was visible through the front windshield and driver's side window and the accused was observed by police putting a condom on his penis; he was charged and convicted of indecency. The appeal concerned whether the trial judge ought to have relied upon expert opinion of harm in rendering a guilty verdict. In rendering the appeal decision, Justice Panet indicated that Labaye established that the "requirement for evidence is ... only established as a 'general rule" " but that "there are obvious cases where no one could argue that the conduct proved in evidence is compatible with the proper functioning of society." 181 Therefore, per Justice Panet, there are cases "which are exceptions to the general rule, where no evidence is required because the nature and the degree of harm which makes it incompatible with the proper functioning of society is obvious." 182

Through the Labaye test, what causes harm to political values is now an open-ended question, allowing the judiciary to insert their own knowledge into the evidentiary gap to criminalize certain kinds of sexual practices and materials. The trouble of those who seek to govern themselves according to the logic of the Supreme Court in Labaye is "how to determine what degree of dangerousness will give rise to a criminal prosecution." 183

Justice Panet obviated the need for expert opinion in Sheik as in these circumstances "opinion evidence is superfluous and unnecessary," 184 similarly to how Justice Provost in Desmarais obviated expert evidence because of how obvious the indecent act was in the presence of children. ${ }^{185}$ However, we believe that this is precisely the point of expert evidence in these cases; when a trier of fact is left to render a verdict on a sexual practice (one of many sexual practices that have changed alongside sexual mores and perspectives), expert evidence allows the fact-finder "to form a correct judgment on a matter if ordinary persons are unlikely to do so without the assistance of persons with special knowledge."186 In other words, judicial knowledge, while significant, is neither equal nor translatable to the special knowledge of experts crafted in sexual politics, and what are "obvious" harms to some may be contrarily viewed by others. With the Labaye test, as conveniently amorphous as it is, positioning (risk of) harm as a threat to political values allows judicial knowledge to spread through the field of sexual politics and criminalize that which interferes with their vision of a properly functioning society.

Finally, in R. v. Coldin, the accuseds were charged with public nudity. ${ }^{187}$ The first accused, Mr. Coldin, was observed by witnesses walking down a highway, at a park, near a nudist camp, and at a Tim Horton's drive-through with his genitals and buttocks uncovered. Coldin was charged with four counts of public nudity. Coldin and the second accused, Mr. Cropper, 
were observed at an A \& W drive-through by a witness who claimed they were both naked. ${ }^{188}$ Cropper was charged with one count of public nudity. Drawing upon Labaye, Justice Douglas determined that Cropper was not guilty of public nudity as he had been wearing a thong at the drive-through ${ }^{189}$ and the witness of Cropper gave inconsistent evidence about Cropper suggesting that there was a reasonable doubt as to the extent of his nudity. ${ }^{190} \mathrm{In}$ turning to Coldin, Justice Douglas indicated that Coldin was never entirely naked as he had footwear and a cellphone holder on. ${ }^{191}$ While near nudity was certainly not a public norm, and Coldin's conduct created a significant risk of harm to the privacy rights of those forced to observe him, ${ }^{192}$ the Justice was not convinced that "the sort of harm to the privacy interests of the clothed or to society at large is so great as to be called incompatible with the proper functioning of society." 193 In addition, Justice Douglas recognized that "there is no direct sort of evidence that suggests ... that public displays of nudity might or might not predispose others to anti-social behaviours." ${ }^{" 194}$ However, the Justice did note "the potential for tensioned responses — breaches of the peace — when such confrontations occur." ${ }^{\text {"195 }}$ While the Crown failed to prove indecency, the embedded notion of public order supported a guilty verdict for Coldin. While the Justice did not find proof of actual physical or actual psychological harm to those involved, ${ }^{196}$ "what perhaps needs somewhat more emphasis in the application of this [Labaye] test to matters of public order as opposed to public indecency is the notion that harm can befall not only individuals, but society."197 Justice Douglas goes on to state:

[I]n the context of an application of the [Labaye] harm test under the rubric of assessing public order, the focus is not so much on how the players hurt themselves or those who stumble onto the activity in question. It, rather, is on the significantly more ethereal notion of "public order", or the "King's peace" etc.

Given the very real and difficult philosophical issues of whether it makes any real sense to talk of the welfare of society as distinct from anything other than a consideration of the welfare of many particular individuals.

The real issue, thus, in the context of applying a harm test developed in a significantly different context to the notion of public order is whether I can conclude that the Crown has proven a degree of harm incompatible with public order.... I believe they have.

Here, I agree and have found in the context of the indecency test that the harm to the participants did not rise to the level of diagnosable psychological harm. However, these same and varied people were clearly harmed to the degree that the social order or milieus in which they carried on their lives was interrupted sufficiently to put a stop to how they were then and there carrying on their day to day business of driving on a public road, going for a swim, walking in a public park, serving coffee or selling hamburgers. In my view, our Queen's Peace was clearly breached when the actions of the Defendants created such concern among and interference with these individuals. ${ }^{198}$

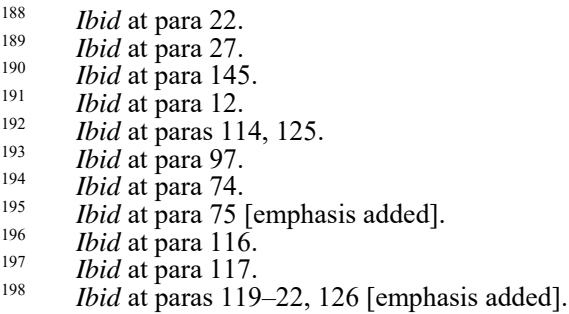


In sum, Justice Douglas drew upon Labaye to query the harm imposed upon the public order rather than in indecency- and obscenity-based charges. While the Justice believed that Coldin did not engage in an indecent act that rose beyond the Labaye test's threshold of risk of harm in terms of actual harm, the ethereal notion of public order was used to substantiate harm done to societal welfare and to the potential risk such harm could impose upon others in society. The potential tensions when others may be confronted, inspired, or moved by near nude exposure was deemed harmful enough to justify a public order conviction for Coldin. The Court was able to use the Labaye calculus to establish a lower threshold of harm for public order offences, one that has disturbingly similar resonance to the retired community standards of tolerance of harm test. Through the attitudinal and liberty-based affronts of the Labaye harm test, Justice Douglas noted that offences of public order required something less than the Labaye quantum of objective harm. Besides being another example of the pliability of Labaye in non-indecency and obscenity contexts, the case illustrates what happens when one lowers the harm quantum that Labaye attempts to create in indecency and obscenity cases - the test more closely resembles the community standards of tolerance of harm test, and no evidence is required.

\section{IN THE LABAYE WHEELHOUSE: Neither a BAwdy House Nor Prostitution Be}

As we indicated above, the Labaye test aimed to solve the fogginess swirling around the term "harm" within indecency and obscenity jurisprudence. As we would expect, applications of Labaye were used in this regard. In particular, the Labaye framework was drawn upon for those cases that involved an accused charged with keeping a bawdy house (whether for acts of indecency or prostitution), a charge that has now been amended solely to keeping a bawdy house for the purposes of acts of indecency. For example, in $R$. $v$. Ponomarev, the accused was charged with keeping a bawdy house. ${ }^{199}$ The location in question was a massage parlour. Drawing upon Labaye, Justice Chisvin determined that $\mathrm{Mr}$. Ponomarev was not guilty, as the payment of money for masturbating clients within the massage parlour was for a full body massage, and the act of masturbation was optional at no additional fee. Furthermore, given that these acts are "done in private, as part of a massage, participated in voluntarily by all individuals, and a fee was paid regardless of whether or not the act[s] took place," the Justice was not satisfied that the Crown had met its onus that the conduct constituted prostitution. ${ }^{200}$ A simple application of Labaye harm types prevented the Court from finding liberty affronts, predisposition to anti-social attitudes, nor participantbased harms.

Other examples include cases where an accused was charged with being found in a bawdy house without a lawful excuse. In R. c. Marceau, ten applicants (eight female dancers, the doorman, and a customer) were charged and convicted with unlawfully being present in a bawdy house. ${ }^{201}$ However, Justice Hilton, in writing for the majority, quashed the conviction and ordered a new trial. Drawing upon Labaye, Justice Hilton indicated that " $[\mathrm{t}]$ he need to

Ibid at para 29; recall at the time a bawdy house offence included practices of indecency and prostitution.

2010 QCCA 1155; again, the case was prosecuted before the bawdy house provision removed prostitution as a constituting circumstance. 
adjust the definition of prostitution, especially the component 'exchange of sexual favours' is constant in a rapidly changing environment." 202 Here, the Justice was searching for a means of prosecution in the void of harm when Labaye criteria are applied. That is, a more flexible prostitution interpretation might catch conduct that the Labaye harm calculi missed under the indecency adjudication. Justice Hilton went on to state:

\begin{abstract}
For example, should a private chat on the telephone for a fee with a person paid to arouse the caller and incite $\mathrm{him} /$ her to self-gratification amount to an act of prostitution and make the place where the calls are answered a common bawdy-house? Is the owner of such business a person living on the avails of prostitution of another person? What about a similar private interaction online when the person paid is performing sexually explicit acts designed to arouse the paying watcher who can masturbate in private? Is the place where the paid person is performing a common bawdy-house? Is the operator of the website who collects the fees living on the avails of prostitution? What about places where a paying client in a private booth can observe a nude dancer behind a glass while masturbating? Are they common bawdy-houses? These examples ... demonstrate the need to refer to objective criteria to avoid unacceptable vagueness. ${ }^{203}$
\end{abstract}

Justice Hilton determined that the bar in which the appellants were found did not constitute a bawdy house, indecency was not proven, nor were the services offered prostitution. ${ }^{204}$ With the difficulty of establishing Labaye-style harms in the bawdy house context, and given the removal of prostitution from the bawdy house definition, it may prove harder to prosecute bawdy house offences going forward. Investigators may choose instead to focus on prostitution-related offences drafted during the Harper era in response to the Canada (Attorney General) v. Bedford ${ }^{205}$ case (a matter for another article). As the preceding sections make clear, despite the difficulty in establishing bawdy house violations, the legacy of Labaye is as much discursive as precedential, as indicated by its use in civil, regulatory, constitutional, military sentencing, and non-indecency/obscenity criminal contexts. If the prosecution of obscenity and indecency seems to have slowed in the wake of Labaye, its main impact may be the wide discussion of harms that courts seem to be having across a wide variety of adjudications. Labaye may be changing the way courts speak about harm in a general sense.

\title{
XIII. Discussion: LABAYE CREeP
}

As we have stated elsewhere, after Labaye, the posited harms-based test became a legal and legitimate technology of risk, where the risk, much like other risk technologies, is not regarded as intrinsically real, "but as a particular way in which problems are viewed or imagined and dealt with." ${ }^{206}$ The malleability of harm within Labaye allows it to act like a "veritable joker" card with certain risks being much more readily assumed to cause harm to society. ${ }^{207}$ Once we supplant this argument with our examination of how courts have applied

\footnotetext{
$202 \quad$ Ibid at para 79.

203 Ibid at paras 79-80 [emphasis added].

$204 \quad$ Ibid at paras 83-85.

$205 \quad 2013$ SCC 72.

206 Nikolas Rose, Pat O’Malley \& Mariana Valverde, “Governmentality” (2006) The University of Sydney, Sydney Law School, Legal Studies Research Paper No 09/94 at 18, online: <ssrn.com/abstract= $1474131>$.

207 Mariana Valverde, "The Harms of Sex and the Risks of Breasts: Obscenity and Indecency in Canadian Law” (1999) 8:2 Soc \& Leg Stud 181 at 184.
} 
the harms-based test since Labaye, our findings could not be any closer to this reality. We view the courts' attempts to analytically (and arguably, paradoxically) contort the Labaye decision as a means to fill the evidentiary vacuum left behind by the very harms-based test it derived from. Put differently, the Labaye test widens the boundaries of state intervention "because of perceived threats to abstract political values like autonomy, liberty and equality, irrespective of any actual or tangible harms caused." 208

The Labaye harm test, at its least effective, fosters opaqueness and fogginess. If the courts' willingness is to see harm as comprised of possibilities of unformed risks, the conception of harm is once again rooted in a judge's perceptions of fear of harm or in threats to political values that need to be protected for the benefit of societal good. In either case, harm is neither empirical nor purely objective. In both cases, harm becomes ethereal, constructed and simultaneously abstract. Inconsistencies in the judicial approach in applying Labaye will ensue if left unrecognized any further, resulting in a lack of clarity or even potential devolution to previous jurisprudential calculations of harm. This fogginess was the problem that Labaye aimed to solve. There is little evidence that it succeeded. In fact, we note that the Labaye harm test seems to have moved to other areas of law unrelated to obscenity and indecency in some adjudications. It has provided an interesting analytic for the measuring of harm across a variety of case treatments.

Despite the Supreme Court's demand in Labaye for positive knowledge of (risk of) harm, Labaye is no horse of a different colour; much like its legal predecessors (the community standards tests), it remains a legal construct devoted mainly to protecting a normative vision of society ${ }^{209}$ rather than promoting human sexuality, freedom of expression, and the creation, production, and dissemination of materials that have educational or artistic merit.

These critiques demonstrate some of the potential hazards in the cases we have reviewed above. The Labaye harm test was a construct meant to determine harm in the particular criminal circumstances of indecency and obscenity-related offences. Its call for expert evidence where necessary was a welcome clarification, but its incantations that extreme types of expression or conduct that posit significant risks may still satisfy the type and quantum of harm becomes more problematic when applied to other areas of law.

Above, we have seen courts willing to use Labaye harm in a discursive manner to buttress Charter-based section 1 justificatory analysis, administrative standard of review analysis, and objectivity in the context of sentencing law. While there is an intuitive seductiveness to these transmogrifications (or Labaye creep, if you will), one cannot lose sight of the fact that Labaye was decided in an area where the measurement of harm is particularly fraught sexual expression and conduct. Should the same balancing acts as the harm test be applied in these other contexts where other interests and complications may apply?

Certainly, the Labaye decision has given effect to conceptions of sexual dynamism in adjudications - even in civil cases where defamation was alleged — but these findings must be measured against the pliability of this dynamism. Above, we have seen examples where 
courts have troubled the harms of child exploitation using this dynamism as an excuse, while other courts seem to argue that the same crimes are so obviously harmful that empirical evidence to prove harm may not even be necessary. That same dynamism has forced courts into an analytical holding pattern in adjudicating bawdy house offences now that prostitution has been removed from section 197 of the Criminal Code. If a swinger's club cannot produce bawdy house indecency harms, how can a massage parlour? The result is that courts are being forced to choose between not guilty verdicts or, alternatively, creating obvious harms and equating these with objectively ascertainable harms. And even still, when we see Labaye transmogrified into the public order realm, we have seen an example where a court finds that public nudity might not meet the quantum of harm to violate the indecency test of Labaye, but when the test is retooled in other criminal public order spheres, the harms are obvious and thus objective.

If the importation of Labaye harms into other areas of legal adjudication seems to create unpredictability in some ways, it should be no surprise. The Supreme Court has previously rejected a particular harm theory as a principle of fundamental justice in R. v. Malmo-Levine; $R$. v. Caine ${ }^{210}$ when, in the context of marijuana offences, the majority rejected the argument that the offence was unconstitutional on the basis that criminal law should only be enacted according to conceptions of J.S. Mill's harm principle: that one's freedom should only be restricted when causing harm to others. ${ }^{211}$ At paragraph 126, the heading reads that "The Harm Principle Is Not a Manageable Standard Against Which to Measure Deprivation of Life, Liberty or Security of the Person" and the majority goes on to write that "allegations and counter-allegations of non-trivial harm can be marshalled on every side of virtually every criminal law issue." 212 The majority then quotes from B. E. Harcourt, "The Collapse of the Harm Principle":

The harm principle is effectively collapsing under the weight of its own success. Claims of harm have become so pervasive that the harm principle has become meaningless: the harm principle no longer serves the function of a critical principle because non-trivial harm arguments permeate the debate. Today, the issue is no longer whether a moral offense causes harm, but rather what type and what amount of harms the challenged conduct causes, and how the harms compare. On those issues, the harm principle is silent. ${ }^{213}$

2003 SCC 74 [Malmo-Levine; Caine].

See John Stuart Mill, On Liberty, 2nd ed (London: John W Parker and Son, West Strand, 1859) at 21-22 [emphasis added]:

The object of this Essay is to assert one very simple principle, as entitled to govern absolutely the dealings of society with the individual in the way of compulsion and control, whether the means used be physical force in the form of legal penalties, or the moral coercion of public opinion. That principle is, that the sole end for which mankind are warranted, individually or collectively, in interfering with the liberty of action of any of their number, is self-protection. That the only purpose for which power can be rightfully exercised over any member of a civilized community, against his will, is to prevent harm to others. His own good, either physical or moral, is not a sufficient warrant.... The only part of the conduct of any one, for which he is amenable to society, is that which concerns others. In the part which merely concerns himself, his independence is, of right, absolute.

Malmo-Levine; Caine, supra note 210 at para 127; for an advanced discussion, see Kent Roach, "Mind the Gap: Canada's Different Criminal and Constitutional Standards of Fault" (2011) 61:4 UTLJ 545. Malmo-Levine; Caine, ibid, citing BE Harcourt, "The Collapse of the Harm Principle" (1999) 90:1 J Crim L \& Criminology 109 at 113 [emphasis in original]. 
The majority dismisses the Millian harm principle by noting that "the existence of harm (however defined) does no more than open a gateway to the debate; it does not give any precise guidance about its resolution." 214

Harm, however defined, only opens debate, according to this majority. The deficiencies outlined by the Supreme Court itself, two years before its decision in Labaye, are prescient. The leaking of the Labaye harm calculus past its legal purpose of establishing aspects of the actus reus of indecency and obscenity-based offences and into the other adjudicative legal realms must similarly be problematized. Surely the Labaye harm calculus did not improve on the Millian formulation of harm; if anything, it simply repackaged the principle to be applicable to the limited offences at hand. Its proliferation into the judicial prose of cases we have reviewed is a somewhat surprising and stunning development, in light of the philosophical objections of the majority in Malmo-Levine; Caine.

\section{Concluding Thoughts: A "Cautious Step" or Caution to The Wind?}

By examining the historical developments of indecency and obscenity in Canadian criminal law in four distinct phases, our article was an attempt to galvanize attention towards the "cautious steps" taken by courts in indecency and obscenity cases in the post-Labaye era. While we applaud the Supreme Court's retirement of the community standards of tolerance test in favour of a modern iteration, we lament how the current harms-based test has been implemented within case adjudication since its inception in Labaye. As we have indicated elsewhere, we do not wish for the discussions surrounding indecency, obscenity, and harmsbased testing "to [become] stunted as we lie in wait for the next important Supreme Court of Canada case or for the next activist cause." ${ }^{215}$ Building upon our previous work, and coupled with findings in this article, we proceed to take another "step" forward and assert, that with the Labaye test, we still have a lack of clarity as to the meaning of harm postCharter. The continued opaqueness and fogginess of this term should prompt a greater concern in the judiciary. In striving to develop a more principled understanding of harm in a number of cases post-Labaye, the judiciary continue to reconstitute and fill evidentiary vacuums with circumstantial evidence, inferences, and intangible harms.

Indeed, the use of the Labaye harm test in Canada and its proliferation as a tool of reasoning in establishing harms across a number of legal areas means that we may be witnessing the expansion of the evidentiary vacuum we had earlier cautioned against, coupled with, on occasion, the judicial filling of these vacuums with unsubstantiated or illperceived risks of harm. Our article reveals the inconsistencies in the judicial approach to the Labaye test, queries the direction to which the Labaye era is taking us in terms of harm assessment, and considers whether a more principled and focused definition of harm is needed for the courts to apply in indecency and obscenity cases and beyond.

The Labaye harm test projects a normative vision of society. If the Labaye vision of harm is aimed, as the Supreme Court itself states, at ensuring the "proper functioning of society," 
the courts maintain a status quo which holds issues of sex and sexuality at arm's length and subordinates their social value through overreaching constructs of, in some cases, nonempirical harm; however, that same normative construction now becomes possible across areas of speech and conduct that transcend the sexually illicit: the political, administrative adjudication, sentencing law, military law, public order offences, defamation law, and in many other possible adjudications. ${ }^{216}$ Legal definitions matter, and the judiciary has the ability to critically shift legal discourse to reposition power and restructure the law's placement in society through case adjudication. Legal clarity surrounding the definition of harm is no exception to this cause. A good start would be limiting the test to use in indecency and obscenity-based offences. It would be better to see declaratory prose from the Supreme Court that the Labaye harm test is not the arbiter of harm assessment in Canada. Then we could recede to a more modest advocacy goal, problematizing the test in the context of sexual speech and conduct. Alternatively, the use of the test in other areas of law should be moderated by a strict requirement of objective evidence for harm. When harm is assessed in non-sexual contexts, constructs like risk prevention and "terror attack" quanta of harm, enmeshed in the Labaye test, could obviate the need for compelling evidence of harm. Through our findings presented here, we can begin to stem the flow of political abstractions the Labaye test fosters and take a modest step forward in closing the evidentiary vacuum in the process. 


\section{APPENDIX: \\ BREAKDOWN OF APPLICATIONS OF \\ LABAYE IN SAMPLE CASES SINCE 2005}

\begin{tabular}{|c|c|c|c|c|}
\hline Court Case & Court Level & Issue & Application of Labaye & Ruling \\
\hline $\begin{array}{l}\text { Greater Vancouver } \\
\text { Transportation } \\
\text { Authority v. } \\
\text { Canadian Federation } \\
\text { of Students - British } \\
\text { Columbia } \\
\text { Component, } 2009 \\
\text { SCC } 31\end{array}$ & $\begin{array}{l}\text { Supreme } \\
\text { Court of } \\
\text { Canada }\end{array}$ & $\begin{array}{l}\text { Transit authorities' advertising } \\
\text { policies permitting commercial } \\
\text { but not political advertising; } \\
\text { whether policies infringe } \\
\text { freedom of expression }\end{array}$ & $\begin{array}{l}\text { Limits of advertising are } \\
\text { contextual; drew upon Labaye } \\
\text { to say what may be indecent } \\
\text { in one public location may not } \\
\text { be indecent in another private } \\
\text { location }\end{array}$ & Appeal dismissed \\
\hline $\begin{array}{l}\text { R. v. Smickle, } 2012 \\
\text { ONSC } 602\end{array}$ & $\begin{array}{l}\text { Ontario } \\
\text { Superior Court } \\
\text { of Justice }\end{array}$ & $\begin{array}{l}\text { Accused challenged the } \\
\text { constitutionality of mandatory } \\
\text { minimum sentence for } \\
\text { possession of loaded firearm }\end{array}$ & $\begin{array}{l}\text { Used as example that Court } \\
\text { has advocated for an objective } \\
\text { standard rather than } \\
\text { undertaking analysis of } \\
\text { standards of tolerance in the } \\
\text { community }\end{array}$ & Appeal allowed \\
\hline $\begin{array}{l}R . v . J R, 2006 \text { CanLII } \\
22658\end{array}$ & $\begin{array}{l}\text { Ontario } \\
\text { Superior Court } \\
\text { of Justice }\end{array}$ & $\begin{array}{l}\text { Whether JD and JR committed } \\
\text { Count } 1 \text { - sexual assault on KP } \\
\text { and Count } 2 \text { - gang sexual } \\
\text { assault on KP }\end{array}$ & $\begin{array}{l}\text { Footnote where judge } \\
\text { recognized that findings of } \\
\text { facts are made uninfluenced } \\
\text { by judge's own sexual mores, } \\
\text { and that some people in } \\
\text { society do willingly engage in } \\
\text { multi-partner sex }\end{array}$ & $\begin{array}{l}\text { JR Count } 1 \text { found } \\
\text { guilty, Count } 2 \\
\text { found not guilty; } \\
\text { JD Count } 1 \text { found } \\
\text { guilty, Count } 2 \\
\text { found not guilty }\end{array}$ \\
\hline $\begin{array}{l}\text { Bedford v. Canada } \\
\text { (Attorney General), } \\
2010 \text { ONSC } 4264\end{array}$ & $\begin{array}{l}\text { Ontario } \\
\text { Superior Court } \\
\text { of Justice }\end{array}$ & $\begin{array}{l}\text { Applicants declare that adult } \\
\text { prostitution provisions of } \\
\text { Criminal Code are } \\
\text { unconstitutional }\end{array}$ & $\begin{array}{l}\text { Drew upon Labaye to find } \\
\text { that the objectives of the } \\
\text { bawdy house provisions for } \\
\text { the purpose of prostitution are } \\
\text { combating neighbourhood } \\
\text { disruption and disorder and } \\
\text { the safeguarding of public } \\
\text { health and safety }\end{array}$ & $\begin{array}{l}\text { Application } \\
\text { granted }\end{array}$ \\
\hline $\begin{array}{l}\text { R. v. Katigbak, } 2011 \\
\text { SCC } 48\end{array}$ & $\begin{array}{l}\text { Supreme } \\
\text { Court of } \\
\text { Canada }\end{array}$ & $\begin{array}{l}\text { Accused charged with one } \\
\text { count of child pornography; } \\
\text { whether accused's actions } \\
\text { constituted artistic merit or } \\
\text { public good in light of } \\
\text { accused's testimony }\end{array}$ & $\begin{array}{l}\text { Majority drew upon Labaye to } \\
\text { argue that any risk of harm is } \\
\text { undue within the meaning of } \\
\text { the provision; Justices LeBel } \\
\text { and Fish disagree, suggesting } \\
\text { specific harms, not generic } \\
\text { risk of harm, must be present }\end{array}$ & Appeal allowed \\
\hline
\end{tabular}




\begin{tabular}{|c|c|c|c|c|}
\hline Court Case & Court Level & Issue & Application of Labaye & Ruling \\
\hline $\begin{array}{l}\text { R. v. Kouri, } 2005 \\
\text { SCC } 81\end{array}$ & $\begin{array}{l}\text { Supreme } \\
\text { Court of } \\
\text { Canada }\end{array}$ & $\begin{array}{l}\text { Accused was charged with } \\
\text { keeping a common bawdy } \\
\text { house for the practice of } \\
\text { indecent acts; to determine } \\
\text { whether criminal indecency } \\
\text { took place }\end{array}$ & $\begin{array}{l}\text { Majority drew upon Labaye to } \\
\text { argue that the conduct did not } \\
\text { constitute criminal indecency } \\
\text { as there was no significant } \\
\text { risk of harm to public's } \\
\text { autonomy, liberty, health, or } \\
\text { the inducement of anti-social } \\
\text { attitudes; Justices Bastarache } \\
\text { and LeBel disagree, } \\
\text { suggesting that because of the } \\
\text { context in which the acts } \\
\text { occurred, reasonable steps } \\
\text { were not taken to ensure } \\
\text { privacy and the standard of } \\
\text { tolerance for these acts in } \\
\text { society was not met. }\end{array}$ & Appeal dismissed \\
\hline $\begin{array}{l}\text { Reference re: Section } \\
293 \text { of the Criminal } \\
\text { Code of Canada, } \\
2011 \text { BCSC } 1588\end{array}$ & $\begin{array}{l}\text { Supreme } \\
\text { Court of } \\
\text { British } \\
\text { Columbia }\end{array}$ & $\begin{array}{l}\text { British Columbia Government } \\
\text { asked Court whether the } \\
\text { prohibition of the practice of } \\
\text { polygamy is consistent with the } \\
\text { freedoms underscored in the } \\
\text { Charter; specifically whether } \\
\text { section } 293 \text { of the Criminal } \\
\text { Code (the polygamy provision) } \\
\text { offends the freedom of religion } \\
\text { by identifiable groups }\end{array}$ & $\begin{array}{l}\text { Used Labaye as an example to } \\
\text { indicate that in order for an } \\
\text { act to be indecent under the } \\
\text { law, it must be objectively } \\
\text { demonstrated to hinder the } \\
\text { proper functioning of society }\end{array}$ & $\begin{array}{l}\text { While section } 293 \\
\text { offends the } \\
\text { freedom of } \\
\text { religion of } \\
\text { identifiable } \\
\text { groups, the } \\
\text { provision is } \\
\text { demonstrably } \\
\text { justified in a free } \\
\text { and democratic } \\
\text { society. }\end{array}$ \\
\hline $\begin{array}{l}\text { R. v. Sharpe, } 2007 \\
\text { BCCA } 191\end{array}$ & $\begin{array}{l}\text { British } \\
\text { Columbia } \\
\text { Court of } \\
\text { Appeal }\end{array}$ & $\begin{array}{l}\text { Accused charged with one } \\
\text { count of gross indecency, one } \\
\text { count of indecent assault, and } \\
\text { one count of sexual assault; } \\
\text { whether the counts should be } \\
\text { amended or quashed }\end{array}$ & $\begin{array}{l}\text { Used Labaye as an example to } \\
\text { indicate that gross indecency } \\
\text { was never defined under the } \\
\text { Criminal Code and that } \\
\text { judges must strike a } \\
\text { precarious balance between } \\
\text { moral and legal standards }\end{array}$ & $\begin{array}{l}\text { Appeal on gross } \\
\text { indecency } \\
\text { dismissed; Count } \\
2 \text { to be quashed; } \\
\text { Count } 1 \\
\text { substituted for } \\
\text { Count } 2\end{array}$ \\
\hline $\begin{array}{l}\text { Marceau c. R., 2010, } \\
\text { QCCA } 1155\end{array}$ & $\begin{array}{l}\text { Quebec Court } \\
\text { of Appeal }\end{array}$ & $\begin{array}{l}\text { Appellants appealing guilty } \\
\text { verdict, which convicted them } \\
\text { of having been found in a } \\
\text { common bawdy house without } \\
\text { a lawful excuse }\end{array}$ & $\begin{array}{l}\text { Drew upon Labaye to argue } \\
\text { that whether prostitution } \\
\text { exists is an objective, not } \\
\text { subjective, inquiry and that } \\
\text { only Parliament can } \\
\text { appropriately and distinctively } \\
\text { define "prostitution" and } \\
\text { "indecency", }\end{array}$ & Appeal dismissed \\
\hline
\end{tabular}




\begin{tabular}{|c|c|c|c|c|}
\hline Court Case & Court Level & Issue & Application of Labaye & Ruling \\
\hline $\begin{array}{l}\text { Kennedy v. Leeds, } \\
\text { Grenville and Lanark } \\
\text { District Health Unit, } \\
2009 \text { ONCA } 685\end{array}$ & $\begin{array}{l}\text { Ontario Court } \\
\text { of Appeal }\end{array}$ & $\begin{array}{l}\text { Appellant operated a sports bar } \\
\text { as a private club for people who } \\
\text { paid a small monthly } \\
\text { membership fee; charged with } \\
\text { offences under the Smoke-Free } \\
\text { Ontario Act relating to the uses } \\
\text { of the premises for smoking by } \\
\text { patrons; appealed decision }\end{array}$ & $\begin{array}{l}\text { The appellant's use of Labaye } \\
\text { was not helpful in } \\
\text { ascertaining the scope of the } \\
\text { definition of "enclosed private } \\
\text { place"" }\end{array}$ & Appeal dismissed \\
\hline $\begin{array}{l}\text { (Re) Roberts, } 2006 \\
\text { NSUARB } 46\end{array}$ & $\begin{array}{l}\text { Nova Scotia } \\
\text { Utility and } \\
\text { Review Board }\end{array}$ & $\begin{array}{l}\text { Intervenors oppose renewal of a } \\
\text { liquor licence for a cabaret } \\
\text { providing "adult" or "exotic" } \\
\text { entertainment, asserting that it } \\
\text { interferes with quiet enjoyment } \\
\text { of neighbourhood properties }\end{array}$ & $\begin{array}{l}\text { Drew upon Labaye to indicate } \\
\text { that there would be significant } \\
\text { risk of harm to women, } \\
\text { children, and seniors living in } \\
\text { the neighbourhood should the } \\
\text { cabaret liquor licence be } \\
\text { granted without conditions } \\
\text { associated with this } \\
\text { neighbourhood disruption and } \\
\text { risk }\end{array}$ & $\begin{array}{l}\text { Cabaret licence } \\
\text { renewed, with } \\
\text { conditions; adult } \\
\text { entertainment } \\
\text { privileges } \\
\text { terminated }\end{array}$ \\
\hline $\begin{array}{l}\text { Drummondville (Ville } \\
\text { de) c. Sylvestre, } 2013 \\
\text { QCCA } 2113\end{array}$ & $\begin{array}{l}\text { Quebec Court } \\
\text { of Appeal }\end{array}$ & $\begin{array}{l}\text { Whether the accused's } \\
\text { proposed swingers club } \\
\text { constituted a commercial } \\
\text { activity based on the } \\
\text { exploitation of sex }\end{array}$ & $\begin{array}{l}\text { Drew upon Labaye to indicate } \\
\text { that the steps taken by the } \\
\text { accused to secure the privacy } \\
\text { of the swingers club from } \\
\text { public view are reasonable } \\
\text { and sound; prospective } \\
\text { members are aware of explicit } \\
\text { sexual activities; therefore, } \\
\text { the exploitation of sex does } \\
\text { not occur }\end{array}$ & Appeal dismissed \\
\hline $\begin{array}{l}\text { R. v. Barabash, } 2012 \\
\text { ABQB } 99\end{array}$ & $\begin{array}{l}\text { Alberta Court } \\
\text { of Queen's } \\
\text { Bench }\end{array}$ & $\begin{array}{l}\text { Accused charged with one } \\
\text { count of making child } \\
\text { pornography, one count of } \\
\text { possessing child pornography; } \\
\text { whether there is an "air of } \\
\text { reality" for the elements of the } \\
\text { defence and the "private use" } \\
\text { exemption }\end{array}$ & $\begin{array}{l}\text { Drew upon Labaye to indicate } \\
\text { that accepted sexual practices } \\
\text { have developed over time; } \\
\text { while the recordings may } \\
\text { constitute child pornography, } \\
\text { the Crown has not proven } \\
\text { beyond a reasonable doubt } \\
\text { that the "private use" } \\
\text { exemption cannot be used by } \\
\text { the accused }\end{array}$ & Not guilty \\
\hline
\end{tabular}




\begin{tabular}{|c|c|c|c|c|}
\hline Court Case & Court Level & Issue & Application of Labaye & Ruling \\
\hline $\begin{array}{l}\text { R. v. Marek, } 2016 \\
\text { ABQB } 18\end{array}$ & $\begin{array}{l}\text { Alberta Court } \\
\text { of Queen's } \\
\text { Bench }\end{array}$ & $\begin{array}{l}\text { Whether search warrants } \\
\text { provided by the police to the } \\
\text { accused were overbroad and } \\
\text { would search the computer and } \\
\text { devices of accused } \\
\text { indiscriminately }\end{array}$ & $\begin{array}{l}\text { Used Labaye as an example to } \\
\text { suggest that society would } \\
\text { have interest in the trial on its } \\
\text { merits in order to protect the } \\
\text { public; however, the } \\
\text { admission of this evidence } \\
\text { would bring the } \\
\text { administration of justice into } \\
\text { disrepute and cannot be } \\
\text { allowed }\end{array}$ & $\begin{array}{l}\text { Evidence seized } \\
\text { from computer } \\
\text { and devices were } \\
\text { excluded }\end{array}$ \\
\hline $\begin{array}{l}\text { R. v. Levkovic, } 2008 \\
\text { CanLII } 48647\end{array}$ & $\begin{array}{l}\text { Ontario } \\
\text { Superior Court } \\
\text { of Justice }\end{array}$ & $\begin{array}{l}\text { Whether section } 243 \\
\text { (Concealing body of child) of } \\
\text { Criminal Code is } \\
\text { unconstitutionally vague }\end{array}$ & $\begin{array}{l}\text { Used Labaye as example to } \\
\text { suggest that courts must } \\
\text { always be on the lookout for } \\
\text { the reality of victimization }\end{array}$ & $\begin{array}{l}\text { Section } 243 \text { of the } \\
\text { Criminal Code is } \\
\text { unconstitutionally } \\
\text { vague; definition } \\
\text { of section } 243 \\
\text { amended }\end{array}$ \\
\hline $\begin{array}{l}\text { R. v. Schmidt, } 2011 \\
\text { ONCJ } 482\end{array}$ & $\begin{array}{l}\text { Ontario Court } \\
\text { of Justice }\end{array}$ & $\begin{array}{l}\text { Appellant argues that cow-share } \\
\text { program is an unlawful attempt } \\
\text { to circumvent the clear } \\
\text { intention of the Milk Act to } \\
\text { limit consumption of } \\
\text { unpasteurized milk to certain } \\
\text { groups }\end{array}$ & $\begin{array}{l}\text { Used Labaye as example to } \\
\text { suggest that there are a } \\
\text { number of reported } \\
\text { circumstances where a private } \\
\text { agreement or privately } \\
\text { conveyed consent has not } \\
\text { acted as an impediment to } \\
\text { prosecution }\end{array}$ & $\begin{array}{l}\text { Application } \\
\text { dismissed }\end{array}$ \\
\hline $\begin{array}{l}\text { R. v. Morel , } 2014 \\
\text { CM } 3011\end{array}$ & Court Martial & $\begin{array}{l}\text { Charged with committing } \\
\text { sexual assault on SJP }\end{array}$ & $\begin{array}{l}\text { Drew upon Labaye to indicate } \\
\text { that the Crown was not able to } \\
\text { prove beyond a reasonable } \\
\text { doubt that the accused's } \\
\text { conduct caused harm or } \\
\text { presented a risk of harm; nor, } \\
\text { if this harm were proven, } \\
\text { would it be incompatible with } \\
\text { society's functioning }\end{array}$ & Not guilty \\
\hline $\begin{array}{l}\text { R. v. Larouche, } 2012 \\
\text { CM } 3009\end{array}$ & Court Martial & $\begin{array}{l}\text { Accused was charged with two } \\
\text { counts of voyeurism, one count } \\
\text { of conduct to the prejudice of } \\
\text { good order and discipline, one } \\
\text { count of harassment, one count } \\
\text { of disgraceful conduct, one } \\
\text { count for having produced nude } \\
\text { visual recordings of a person, } \\
\text { and one count of possession of } \\
\text { child pornography }\end{array}$ & $\begin{array}{l}\text { Drew upon Labaye to suggest } \\
\text { that while voyeurism did } \\
\text { occur, the bizarre } \\
\text { conversations between } \\
\text { Larouche and VC were more } \\
\text { a facet of the relationship than } \\
\text { an intention to cause harm or } \\
\text { offend }\end{array}$ & $\begin{array}{l}\text { Guilty on Counts } \\
4 \text { and } 8 \text {; not guilty } \\
\text { on Counts } 5,6 \\
\text { and } 7\end{array}$ \\
\hline
\end{tabular}




\begin{tabular}{|c|c|c|c|c|}
\hline Court Case & Court Level & Issue & Application of Labaye & Ruling \\
\hline $\begin{array}{l}\text { R. v. Sheikh, } 2008 \\
\text { CanLII } 17311\end{array}$ & $\begin{array}{l}\text { Ontario } \\
\text { Superior Court } \\
\text { of Justice }\end{array}$ & $\begin{array}{l}\text { Whether the appellant engaged } \\
\text { in an indecent act in a public } \\
\text { place witnessed by two or more } \\
\text { persons }\end{array}$ & $\begin{array}{l}\text { Drew upon Labaye to indicate } \\
\text { that expert evidence was not } \\
\text { necessary to suggest that the } \\
\text { act was indecent and was a } \\
\text { significant risk of harm to } \\
\text { society's proper functioning }\end{array}$ & Appeal dismissed \\
\hline $\begin{array}{l}\text { R. v. LaPage, } 2014 \\
\text { ONSC } 5855\end{array}$ & $\begin{array}{l}\text { Ontario } \\
\text { Superior Court } \\
\text { of Justice }\end{array}$ & $\begin{array}{l}\text { Whether the conduct of the } \\
\text { accused constituted an act of } \\
\text { gross indecency }\end{array}$ & $\begin{array}{l}\text { Drew upon Labaye to suggest } \\
\text { that trial judges should be as } \\
\text { objective as possible whether } \\
\text { impugned conduct is merely } \\
\text { immoral as opposed to } \\
\text { criminal }\end{array}$ & Charge dismissed \\
\hline $\begin{array}{l}\text { Alexandre c. R., } 2009 \\
\text { QCCS } 16\end{array}$ & $\begin{array}{l}\text { Quebec } \\
\text { Superior Court }\end{array}$ & $\begin{array}{l}\text { Whether the appellants' } \\
\text { conviction should be upheld, as } \\
\text { they were convicted for being } \\
\text { in a common bawdy house } \\
\text { without lawful excuse }\end{array}$ & $\begin{array}{l}\text { Drew upon Labaye to indicate } \\
\text { that the trial judge did not err } \\
\text { in findings and that it is not } \\
\text { up to the courts to determine } \\
\text { how tolerant a community } \\
\text { may be to alleged acts of } \\
\text { prostitution; the latter is for } \\
\text { the legislators to decide }\end{array}$ & Appeal dismissed \\
\hline $\begin{array}{l}\text { R. c. Giguère, } 2008 \\
\text { QCCQ } 3113\end{array}$ & $\begin{array}{l}\text { Court of } \\
\text { Quebec }\end{array}$ & $\begin{array}{l}\text { Accused charged with living on } \\
\text { the proceeds of prostitution of } \\
\text { several persons, possessing } \\
\text { money and securities through } \\
\text { procuring, possession of } \\
\text { narcotics, and storing firearms } \\
\text { and ammunition in a manner } \\
\text { not in conformity with the law }\end{array}$ & $\begin{array}{l}\text { Drew upon Labaye to suggest } \\
\text { that the assessment of an } \\
\text { accused's criminal } \\
\text { responsibility and moral } \\
\text { blameworthiness relates to the } \\
\text { violations of officially } \\
\text { recognized social norms }\end{array}$ & Guilty \\
\hline $\begin{array}{l}\text { R. v. Murphy, } 2010 \\
\text { NSPC } 4\end{array}$ & $\begin{array}{l}\text { Nova Scotia } \\
\text { Provincial } \\
\text { Court }\end{array}$ & $\begin{array}{l}\text { Accused charged with maiming } \\
\text { a dog, uttering a death threat to } \\
\text { its owner, and using a firearm } \\
\text { without reasonable precautions } \\
\text { for the safety of other persons }\end{array}$ & $\begin{array}{l}\text { Used Labaye as an example } \\
\text { of case before the Supreme } \\
\text { Court of Canada where } \\
\text { "modern" principle of } \\
\text { statutory construction was } \\
\text { reconsidered }\end{array}$ & Not guilty \\
\hline $\begin{array}{l}\text { R. v. Cawthorne, } \\
2014 \text { CM } 1014\end{array}$ & Court Martial & $\begin{array}{l}\text { Accused charged with one } \\
\text { count of possession of child } \\
\text { pornography and one count of } \\
\text { accessing child pornography }\end{array}$ & $\begin{array}{l}\text { Drew upon Labaye to indicate } \\
\text { that a significant risk of harm } \\
\text { would have arisen had the } \\
\text { repatriation of the accused in } \\
\text { Canada been delayed because } \\
\text { the accused was participating } \\
\text { in an international exercise } \\
\text { outside of Canada }\end{array}$ & Guilty \\
\hline
\end{tabular}




\begin{tabular}{|c|c|c|c|c|}
\hline Court Case & Court Level & Issue & Application of Labaye & Ruling \\
\hline $\begin{array}{l}\text { R. v. Lloyd-Trinque, } \\
2015 \text { CM } 3001\end{array}$ & Court Martial & $\begin{array}{l}\text { Charged with two counts of } \\
\text { allegedly committing a sexual } \\
\text { offence against a fellow soldier, } \\
\text { two counts of behaving in a } \\
\text { disgraceful manner, and one } \\
\text { count of conduct to the } \\
\text { prejudice of good order and } \\
\text { discipline }\end{array}$ & $\begin{array}{l}\text { Drew upon Labaye to indicate } \\
\text { that the accused did not } \\
\text { behave in a disgraceful } \\
\text { manner to the complainant } \\
\text { and that no significant risk of } \\
\text { harm occurred to the } \\
\text { complainant }\end{array}$ & Not guilty \\
\hline $\begin{array}{l}\text { Fountain v. British } \\
\text { Columbia College of } \\
\text { Teachers, } 2013 \\
\text { BCSC } 773\end{array}$ & $\begin{array}{l}\text { Supreme } \\
\text { Court of } \\
\text { British } \\
\text { Columbia }\end{array}$ & $\begin{array}{l}\text { Reconsideration of trial } \\
\text { decision, which found appellant } \\
\text { guilty of conduct unbecoming a } \\
\text { member of the teaching } \\
\text { profession and that his actions } \\
\text { brought the profession into } \\
\text { disrepute }\end{array}$ & $\begin{array}{l}\text { Drew upon Labaye to indicate } \\
\text { that appellant's actions did } \\
\text { not present a significant risk } \\
\text { of harm to society's proper } \\
\text { functioning }\end{array}$ & $\begin{array}{l}\text { Appeal allowed; } \\
\text { verdict of not } \\
\text { guilty to be } \\
\text { substituted for } \\
\text { conviction }\end{array}$ \\
\hline $\begin{array}{l}\text { R. c. Colalillo, } 2006 \\
\text { QCCS } 7903\end{array}$ & $\begin{array}{l}\text { Quebec } \\
\text { Superior Court }\end{array}$ & $\begin{array}{l}\text { Accused charged with three } \\
\text { counts of first degree murder; } \\
\text { however, accused died; } \\
\text { nevertheless, court was asked to } \\
\text { render public a series of letters } \\
\text { written by deceased }\end{array}$ & $\begin{array}{l}\text { Drew upon Labaye to indicate } \\
\text { that, without a publication } \\
\text { ban, the letters of the } \\
\text { deceased would have } \\
\text { corrupting effect on public, } \\
\text { loved ones, and children }\end{array}$ & $\begin{array}{l}\text { Publication ban } \\
\text { ordered }\end{array}$ \\
\hline $\begin{array}{l}\text { R. c. Derisca, } 2011 \\
\text { QCCQ } 4148\end{array}$ & $\begin{array}{l}\text { Court of } \\
\text { Quebec }\end{array}$ & $\begin{array}{l}\text { Accused charged with forcing a } \\
\text { person under the age of } 18 \text { to } \\
\text { engage in prostitution, inducing } \\
\text { or attempting to induce } \\
\text { someone into an indictable } \\
\text { offence, exercising control over } \\
\text { the movements of someone } \\
\text { engaging in prostitution, } \\
\text { sexually assaulting, knowingly } \\
\text { uttering to threaten or cause } \\
\text { bodily harm, detaining or } \\
\text { seizing by force, and possessing } \\
\text { a firearm without a licence to } \\
\text { do so }\end{array}$ & $\begin{array}{l}\text { Drew upon Labaye to indicate } \\
\text { that the contact dances with } \\
\text { sexual services offered in the } \\
\text { bar were acts of prostitution }\end{array}$ & $\begin{array}{l}\text { Guilty of charges } \\
1,3,4,5,6,7,9, \\
\text { and } 10 ; \text { acquitted } \\
\text { of charges } 2 \text { and } 8\end{array}$ \\
\hline $\begin{array}{l}\text { Langevin c. TH } \\
\text { Construction Inc., } \\
2016 \text { QCCQ } 14897\end{array}$ & $\begin{array}{l}\text { Court of } \\
\text { Quebec }\end{array}$ & $\begin{array}{l}\text { Whether the plaintiff is owed } \\
\text { compensation for the } \\
\text { defendant's conduct of work in } \\
\text { installing a septic tank on } \\
\text { plaintiff's property }\end{array}$ & $\begin{array}{l}\text { Drew upon Labaye to suggest } \\
\text { that sexual practices } \\
\text { conducted between } \\
\text { consenting adults have a right } \\
\text { to privacy from the public }\end{array}$ & $\begin{array}{l}\text { Condemns } \\
\text { defendant to pay } \\
\text { plaintiff all, with } \\
\text { legal costs added }\end{array}$ \\
\hline
\end{tabular}




\begin{tabular}{|c|c|c|c|c|}
\hline Court Case & Court Level & Issue & Application of Labaye & Ruling \\
\hline $\begin{array}{l}\text { Sylvestre c. } \\
\text { Drummondville (Ville } \\
\text { de), } 2012 \text { QCCS } 698\end{array}$ & $\begin{array}{l}\text { Quebec } \\
\text { Superior Court }\end{array}$ & $\begin{array}{l}\text { Whether the City should issue } \\
\text { licences to the Applicant to } \\
\text { operate a private swingers } \\
\text { social club and renovate the } \\
\text { Applicant's building }\end{array}$ & $\begin{array}{l}\text { Drew upon Labaye to indicate } \\
\text { this issue is about zoning, not } \\
\text { about morality or the } \\
\text { tolerance of citizens }\end{array}$ & $\begin{array}{l}\text { Orders City to } \\
\text { issue Applicant } \\
\text { the licences to } \\
\text { operate a private } \\
\text { swingers social } \\
\text { club and to } \\
\text { renovate the } \\
\text { building }\end{array}$ \\
\hline $\begin{array}{l}\text { R. v. Paquette, } 2014 \\
\text { CM } 2014\end{array}$ & Court Martial & $\begin{array}{l}\text { Accused pled guilty to one } \\
\text { count of accessing child } \\
\text { pornography and one count of } \\
\text { conduct to the prejudice of } \\
\text { good order and discipline }\end{array}$ & $\begin{array}{l}\text { Used Labaye as an example to } \\
\text { indicate that offences such as } \\
\text { these are considered } \\
\text { objectively serious in Canada }\end{array}$ & $\begin{array}{l}\text { Sentenced to } \\
\text { imprisonment for } \\
21 \text { days }\end{array}$ \\
\hline $\begin{array}{l}\text { R. v. Quinn APS } \\
\text { (Sergeant), } 2007 \mathrm{CM} \\
3018\end{array}$ & Court Martial & $\begin{array}{l}\text { Accused is charged with two } \\
\text { counts of assault with a } \\
\text { weapon, one count of behaving } \\
\text { in a disgraceful manner, and } \\
\text { one count of ill-treating a } \\
\text { person who by reason of rank } \\
\text { was subordinate to him }\end{array}$ & $\begin{array}{l}\text { Drew upon Labaye to indicate } \\
\text { that the acts conducted do not } \\
\text { meet the requirements of the } \\
\text { concept of behaving in a } \\
\text { disgraceful manner }\end{array}$ & Not guilty \\
\hline $\begin{array}{l}\text { R. v. Buenacruz, } \\
2017 \text { CM } 4014\end{array}$ & Court Martial & $\begin{array}{l}\text { Accused is charged with one } \\
\text { count of sexual assault, one } \\
\text { count of behaving in a } \\
\text { disgraceful manner, one count } \\
\text { of communication with a } \\
\text { person for the purpose of } \\
\text { obtaining sexual services, one } \\
\text { count of behaving in a } \\
\text { disgraceful manner in exchange } \\
\text { for sex, and one count of } \\
\text { prejudice to good order and } \\
\text { discipline }\end{array}$ & $\begin{array}{l}\text { Drew upon Labaye to indicate } \\
\text { that the acts conducted do not } \\
\text { raise harm or a significant risk } \\
\text { of harm to the level needed to } \\
\text { pose a risk to society's proper } \\
\text { functioning }\end{array}$ & Not guilty \\
\hline $\begin{array}{l}\text { The Canadian Centre } \\
\text { for Bio-Ethical } \\
\text { Reform v. South } \\
\text { Coast British } \\
\text { Columbia } \\
\text { Transportation } \\
\text { Authority, } 2017 \\
\text { BCSC } 1388\end{array}$ & $\begin{array}{l}\text { Supreme } \\
\text { Court of } \\
\text { British } \\
\text { Columbia }\end{array}$ & $\begin{array}{l}\text { Whether the applicant has a } \\
\text { Charter right to place pro-life } \\
\text { advertisements on respondent's } \\
\text { buses }\end{array}$ & $\begin{array}{l}\text { Drew upon Labaye to suggest } \\
\text { that the concept of indecency } \\
\text { is contingent; what is private } \\
\text { in one location and context is } \\
\text { public in another location and } \\
\text { context }\end{array}$ & $\begin{array}{l}\text { Application for } \\
\text { judicial review } \\
\text { dismissed }\end{array}$ \\
\hline $\begin{array}{l}\text { R. v. DM, } 2015 \\
\text { ONSC } 6838\end{array}$ & $\begin{array}{l}\text { Ontario } \\
\text { Superior Court } \\
\text { of Justice }\end{array}$ & $\begin{array}{l}\text { Accused is charged with ten } \\
\text { sexual offences against a child }\end{array}$ & $\begin{array}{l}\text { Drew upon Labaye to put } \\
\text { testimony of LM in context, } \\
\text { suggesting that sex talk and } \\
\text { sexual imagery pervades } \\
\text { mainstream culture }\end{array}$ & Not guilty \\
\hline
\end{tabular}




\begin{tabular}{|c|c|c|c|c|}
\hline Court Case & Court Level & Issue & Application of Labaye & Ruling \\
\hline $\begin{array}{l}\text { R.v. Bastien, } 2016 \\
\text { ONSC } 1166\end{array}$ & $\begin{array}{l}\text { Ontario } \\
\text { Superior Court } \\
\text { of Justice }\end{array}$ & $\begin{array}{l}\text { Accused charged with a } 30- \\
\text { count indictment with offences } \\
\text { of gross indecency, indecent } \\
\text { assault, sexual assault, and } \\
\text { invitation to sexual touching }\end{array}$ & $\begin{array}{l}\text { Drew upon Labaye to indicate } \\
\text { that while terms like } \\
\text { "decency" and "gross } \\
\text { indecency" may be somewhat } \\
\text { imprecise, the offences } \\
\text { themselves are neither vague } \\
\text { nor conceptually amorphous } \\
\text { as to put a potential offender } \\
\text { in peril }\end{array}$ & $\begin{array}{l}\text { All applications } \\
\text { dismissed; } \\
\text { applicants should } \\
\text { be tried on all } 30 \\
\text { counts }\end{array}$ \\
\hline $\begin{array}{l}\text { R. v. Ellison, } 2006 \\
\text { BCPC } 549\end{array}$ & $\begin{array}{l}\text { Provincial } \\
\text { Court of } \\
\text { British } \\
\text { Columbia }\end{array}$ & $\begin{array}{l}\text { Accused is charged with four } \\
\text { counts of indecent assault and } \\
12 \text { counts of gross indecency }\end{array}$ & $\begin{array}{l}\text { Drew upon Labaye to indicate } \\
\text { that the Labaye test would not } \\
\text { be appropriate for this case, } \\
\text { given the historical time } \\
\text { period over which the alleged } \\
\text { acts occurred }\end{array}$ & $\begin{array}{l}\text { Guilty of indecent } \\
\text { assault in counts } 3 \\
\text { and 7; guilty of } \\
\text { gross indecency } \\
\text { in counts } 2 \text { and 6; } \\
\text { guilty of gross } \\
\text { indecency in } \\
\text { counts } 4 \text { and 5; } \\
\text { not guilty of } \\
\text { indecent assault } \\
\text { in count } 12 \text {, but } \\
\text { guilty of common } \\
\text { assault; not guilty } \\
\text { of the remaining } \\
\text { charges }\end{array}$ \\
\hline $\begin{array}{l}\text { R. v. Ponomarev, } \\
2007 \text { ONCJ } 271\end{array}$ & $\begin{array}{l}\text { Ontario Court } \\
\text { of Justice }\end{array}$ & $\begin{array}{l}\text { Accused charged with keeping } \\
\text { a common bawdy house and } \\
\text { knowingly permitting the } \\
\text { premises to be used for the } \\
\text { purpose of a bawdy house }\end{array}$ & $\begin{array}{l}\text { Drew upon Labaye to indicate } \\
\text { that, based on the facts of the } \\
\text { case, the Crown has not } \\
\text { proven beyond a reasonable } \\
\text { doubt that there were "acts of } \\
\text { indecency" practiced at the } \\
\text { premises }\end{array}$ & Not guilty \\
\hline $\begin{array}{l}\text { R. v. Pierce, } 2017 \\
\text { ONCJ } 875\end{array}$ & $\begin{array}{l}\text { Ontario Court } \\
\text { of Justice }\end{array}$ & $\begin{array}{l}\text { Accused charged with one } \\
\text { count of failure to comply with } \\
\text { probation, and one count of } \\
\text { committing an indecent act in a } \\
\text { public place }\end{array}$ & $\begin{array}{l}\text { Drew upon Labaye test to } \\
\text { indicate that the acts } \\
\text { conducted do not prove } \\
\text { beyond a reasonable doubt } \\
\text { that actual harm or significant } \\
\text { risk of harm occurred in } \\
\text { public }\end{array}$ & $\begin{array}{l}\text { Guilty of failure } \\
\text { to comply with } \\
\text { probation; not } \\
\text { guilty of indecent } \\
\text { act }\end{array}$ \\
\hline
\end{tabular}




\begin{tabular}{|c|c|c|c|c|}
\hline Court Case & Court Level & Issue & Application of Labaye & Ruling \\
\hline $\begin{array}{l}\text { R. c. Desmarais, } \\
2008 \text { QCCQ } 7959\end{array}$ & $\begin{array}{l}\text { Court of } \\
\text { Quebec }\end{array}$ & $\begin{array}{l}\text { Accused charged with one } \\
\text { count of indecent act in a public } \\
\text { place; one count of having } \\
\text { committed an indecent act with } \\
\text { the intention to insult or offend; } \\
\text { and one count of having, for } \\
\text { sexual purposes, exposed his } \\
\text { genitals to another person }\end{array}$ & $\begin{array}{l}\text { Drew upon Labaye test to } \\
\text { indicate that the indecent act } \\
\text { raises a significant level of } \\
\text { risk of harm to the 12-year- } \\
\text { old girl and risks society's } \\
\text { proper functioning }\end{array}$ & $\begin{array}{l}\text { Guilty of count } 1 \text {; } \\
\text { acquitted of } \\
\text { counts } 2 \text { and } 3\end{array}$ \\
\hline $\begin{array}{l}\text { Chambly (Ville de) c. } \\
\text { Deschênes, } 2006 \\
\text { QCCM } 3\end{array}$ & $\begin{array}{l}\text { Quebec } \\
\text { Municipal } \\
\text { Courts }\end{array}$ & $\begin{array}{l}\text { Whether the defendant illegally } \\
\text { amended a submitted plan for } \\
\text { obtaining a building permit }\end{array}$ & $\begin{array}{l}\text { Drew upon Labaye to suggest } \\
\text { that criminal offences must be } \\
\text { defined in such a way that } \\
\text { citizens, police, and courts } \\
\text { have a clear idea of what acts } \\
\text { are to be prohibited }\end{array}$ & Guilty \\
\hline $\begin{array}{l}\text { R. c. Fournier, } 2009 \\
\text { QCCM } 70\end{array}$ & $\begin{array}{l}\text { Quebec } \\
\text { Municipal } \\
\text { Courts }\end{array}$ & $\begin{array}{l}\text { Accused charged with allegedly } \\
\text { committing an indecent act in a } \\
\text { public place in the presence of } \\
\text { others }\end{array}$ & $\begin{array}{l}\text { Drew upon Labaye to suggest } \\
\text { that the Crown, through their } \\
\text { circumstantial evidence, did } \\
\text { not prove beyond a reasonable } \\
\text { doubt that the act conducted } \\
\text { was indecent }\end{array}$ & $\begin{array}{l}\text { Defendant } \\
\text { acquitted }\end{array}$ \\
\hline $\begin{array}{l}\text { R. c. Alexandre, } 2007 \\
\text { QCCM } 346\end{array}$ & $\begin{array}{l}\text { Quebec } \\
\text { Municipal } \\
\text { Courts }\end{array}$ & $\begin{array}{l}\text { All accuseds charged with } \\
\text { having been without lawful } \\
\text { excuse in a bawdy house; one } \\
\text { accused charged with } \\
\text { possession of cannabis } \\
\text { cigarettes }\end{array}$ & $\begin{array}{l}\text { Drew upon Labaye to indicate } \\
\text { that prostitution is a harmful } \\
\text { phenomenon and a degrading } \\
\text { and dehumanizing activity }\end{array}$ & $\begin{array}{l}\text { All defendants } \\
\text { guilty }\end{array}$ \\
\hline $\begin{array}{l}\text { Papillon Rose (Re), } \\
2015 \text { CanLII } 9713\end{array}$ & $\begin{array}{l}\text { Quebec } \\
\text { Liquor, } \\
\text { Racing and } \\
\text { Gaming } \\
\text { Authority }\end{array}$ & $\begin{array}{l}\text { Whether the application can } \\
\text { replace the temporary liquor } \\
\text { licence with a permanent } \\
\text { licence that authorizes dance } \\
\text { shows and nudity }\end{array}$ & $\begin{array}{l}\text { Drew upon Labaye to indicate } \\
\text { that the application has made } \\
\text { verbal and written } \\
\text { commitments to ensure that } \\
\text { reasonable steps are taken for } \\
\text { the showing of dances and } \\
\text { nudity away from public view }\end{array}$ & $\begin{array}{l}\text { Liquor licence } \\
\text { authorized with } \\
\text { conditions }\end{array}$ \\
\hline $\begin{array}{l}\text { R. v. Simpson, } 2006 \\
\text { NSSC } 404\end{array}$ & $\begin{array}{l}\text { Nova Scotia } \\
\text { Supreme } \\
\text { Court }\end{array}$ & $\begin{array}{l}\text { Applicant brought a Charter } \\
\text { challenge to the Controlled } \\
\text { Drug and Substances Act, } \\
\text { alleging that certain provisions } \\
\text { infringe on section } 7 \text { Charter } \\
\text { rights by making it an offence } \\
\text { to cultivate, possess, and/or } \\
\text { distribute marijuana }\end{array}$ & $\begin{array}{l}\text { Drew upon Labaye to correct } \\
\text { the applicant in his } \\
\text { interpretation of Labaye and } \\
\text { the harm principle; Labaye is } \\
\text { not appropriate for the case at } \\
\text { hand and was rejected }\end{array}$ & $\begin{array}{l}\text { Application was } \\
\text { dismissed and the } \\
\text { matter proceeded } \\
\text { to trial }\end{array}$ \\
\hline
\end{tabular}




\begin{tabular}{|c|c|c|c|c|}
\hline Court Case & Court Level & Issue & Application of Labaye & Ruling \\
\hline $\begin{array}{l}J M M v \cdot M C M, 2011 \\
\text { NBQB } 231\end{array}$ & $\begin{array}{l}\text { New } \\
\text { Brunswick } \\
\text { Court of } \\
\text { Queen's } \\
\text { Bench }\end{array}$ & $\begin{array}{l}\text { Motion by the applicant for } \\
\text { interim sole custody of the child }\end{array}$ & $\begin{array}{l}\text { Drew upon Labaye to suggest } \\
\text { that any risk of future harm } \\
\text { must be within the best } \\
\text { interests of the child and } \\
\text { established on a balance of } \\
\text { probabilities }\end{array}$ & $\begin{array}{l}\text { JMM to have sole } \\
\text { custody of child; } \\
\text { MCM will have } \\
\text { reasonable } \\
\text { supervised access } \\
\text { to child }\end{array}$ \\
\hline $\begin{array}{l}\text { R. v. Coldin, [2012] } \\
\text { OJ No } 1009 \text { (QL) }\end{array}$ & $\begin{array}{l}\text { Ontario Court } \\
\text { of Justice }\end{array}$ & $\begin{array}{l}\text { Accused charged with public } \\
\text { nudity }\end{array}$ & $\begin{array}{l}\text { Drew upon Labaye test to } \\
\text { determine whether a risk of } \\
\text { harm to individuals or society } \\
\text { was reasonable; the } \\
\text { confrontation of nudity was } \\
\text { not considered indecent but } \\
\text { was a cause of disturbance to } \\
\text { public order }\end{array}$ & $\begin{array}{l}\text { Accused (Coldin) } \\
\text { convicted of four } \\
\text { counts of public } \\
\text { nudity, and } \\
\text { acquitted of one; } \\
\text { Accused } \\
\text { (Cropper) } \\
\text { acquitted of the } \\
\text { sole count of } \\
\text { public nudity }\end{array}$ \\
\hline $\begin{array}{l}\text { Latreille c. R., } 2007 \\
\text { QCCA } 1330\end{array}$ & $\begin{array}{l}\text { Quebec Court } \\
\text { of Appeal }\end{array}$ & $\begin{array}{l}\text { Appellant convicted at trial of } \\
\text { producing an obscene item }\end{array}$ & $\begin{array}{l}\text { Drew upon Labaye test to } \\
\text { determine whether the } \\
\text { conviction should stand; } \\
\text { appellate justice concluded } \\
\text { that the evidence does not } \\
\text { reach the threshold of undue } \\
\text { exploitation of person seen in } \\
\text { intimate image and no } \\
\text { evidence to suggest that } \\
\text { activities seen in these images } \\
\text { would be incompatible with } \\
\text { the proper functioning of } \\
\text { society }\end{array}$ & $\begin{array}{l}\text { Appeal allowed; } \\
\text { verdict infringes } \\
\text { the judgment of } \\
\text { the Superior } \\
\text { Court and } \\
\text { remedies the } \\
\text { verdict rendered } \\
\text { by the Municipal } \\
\text { Court }\end{array}$ \\
\hline
\end{tabular}


[this page is intentionally blank] 